\title{
Probing the helical integrity of multivicinal all-syn-fluoro alkanes
}

\author{
Nawaf Al-Maharik, ${ }^{a, b}$ David B. Cordes, ${ }^{a}$ Alexandra M. Z. Slawin, ${ }^{a}$ Michael Bühl ${ }^{a}$ and David O'Hagan*a
}

:Received 00th January 20xx,

Accepted 00th January 20xx

DOI: $10.1039 / \times 0 \times x 00000 x$

This study extends our interest in the synthesis and conformational behaviour of all-syn multivicinal fluoro alkane motifs. Specifically an all-syn 1,2,3,6,7,8-hexafluorooctane chain was assembled with a run of three fluorines, of the same stereochemical sense (syn) to the direction of the chain, on each side of an ethylene $\left(-\mathrm{CH}_{2} \mathrm{CH}_{2}-\right)$ spacer to explore if the helical sense of the chain crosses the ethylene bridge. The solid state (X-ray) structure indicated a continuous helix however in solution (NMR) and by DFT computation, although the individual all-syn 1,2,3-trifluoro motifs maintain good helical integrity, the molecule is much more dynamic across the ethylene bridge. It was notable however that a low energy, non-helical conformer has a high molecular dipole $(\mu=$ 7.15D) indicating a role for this skipped motif in soft materials such as liquid crystals or polar polymers.

\section{Introduction}

The consequences of replacing fluorine for hydrogen at $\mathrm{sp}^{3}$ carbon centres remains one of the least studied aspects of structure property relationships in organic chemistry. ${ }^{1}$ This can be contrasted with the rich chemical literature associated with placing fluorine on an aromatic ring, a modification common for example in medicinal chemistry. ${ }^{2}$ Due to this limited attention $w^{3,4}$ and others, ${ }^{5-8}$ have been led to explore the physiochemical properties of partially fluorinated alkyl motifs and this is emerging as an important contemporary focus in organofluorine chemistry. In this context our lab has investigated the synthesis and properties of alkanes with multiple fluoromethylene carbons (-CHF-) joined linearly ${ }^{3}$ and in rings ${ }^{4}$ as summarised in Figure 1 (a) and (b) respectively. Such compounds have vicinally arranged $\mathrm{C}-\mathrm{F}$ bonds and have up to $2^{\mathrm{n}}$ stereoisomers (where $\mathrm{n}$ equals the number of -CHF-stereogenic centres). What emerges is that partial aliphatic fluorination increases molecular polarity due to polarisation of the geminal and vicinal hydrogens ${ }^{9}$ and we have highlighted that this is particularly striking in conformationally constrained all-syn

\footnotetext{
a. EaStCHEM School of Chemistry, University of St. Andrews, St. Andrews, Fife KY16 9ST, UK.Email do1@st-andrews.ac.uk

b. Department of Chemistry, Faculty of Science, An Najah National University,

Nablus, Palestine.

Electronic Supplementary Information (ESI) available: CCDC 1971579. For ESI and
}

tetra- $\mathbf{1}^{4 \mathrm{~d}}$ and hexa- $\mathbf{2}^{4 \mathrm{c}}$ fluorinated cyclohexanes and trifluorocyclopropanes $3 .{ }^{4 a}$

(a)

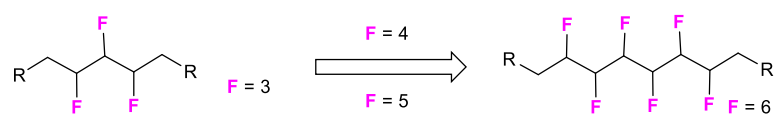

(b)<smiles>FC1CC(F)C(F)CC1F</smiles><smiles>FC1C(F)C(F)C(F)C(F)C1F</smiles>
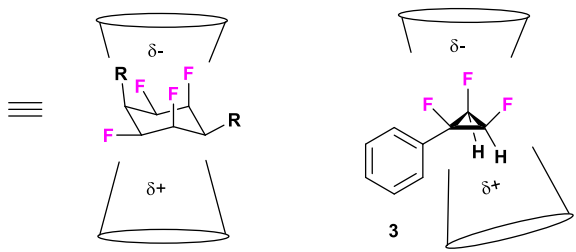

$\mathrm{R}=\mathrm{F}$ or $\mathrm{H}$

(c)

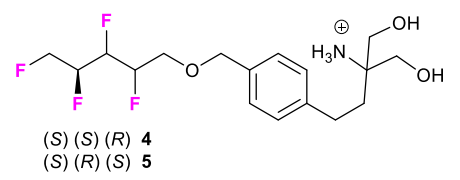

Fig 1. Examples of (a) multivicinal fluoroalkanes, (b) Janus faced fluoro-cycloalkanes and (c) bioactives containing a linear tetrafluoro alkyl motif.

These rings are highly polarised because they have fluorines on one face of the ring and hydrogens on the other. The term 'Janus rings' has been coined ${ }^{10}$ to describe such systems due to the different electrostatic profile of each face, illustrated by the cones in Figure 1. For conformationally free alkane chains of this class, then the polar effects are reduced as the chains can access low polarity conformations. That said, Gilmour's lab has recently shown ${ }^{6 a}$ that different configurations of the fluorines along the tetrafluoro alkane chain in drug analogues $\mathbf{4}$ and $\mathbf{5}$, displayed different physiochemical properties including significant solubility differences, demonstrating that even in linear alkanes, isomers cannot be considered to have equivalent properties. 

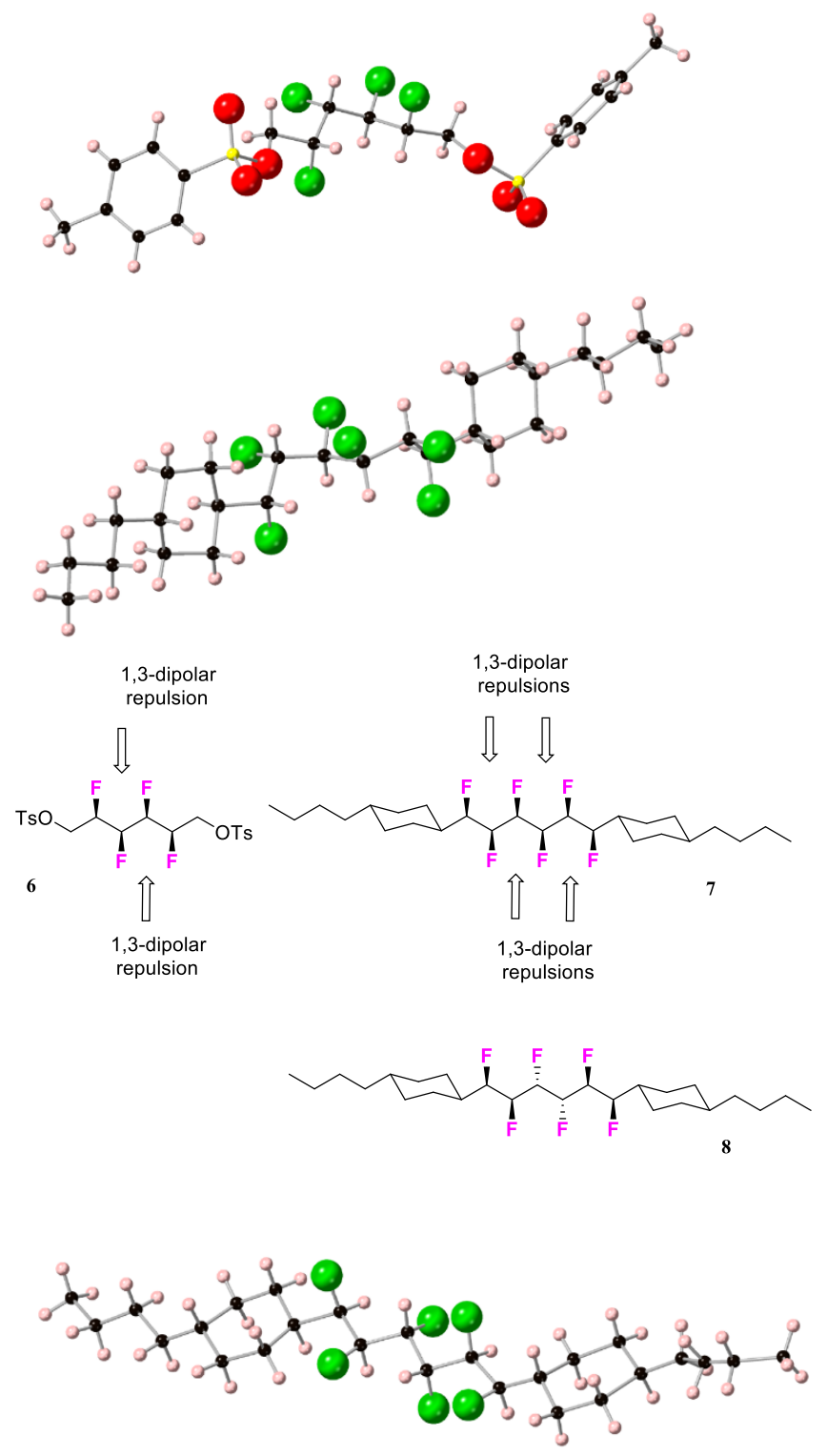

Fig 2. X-ray structures are shown for the helical structures for all-syn isomers $6^{3 \mathrm{~g}}$ and $7,{ }^{3 \mathrm{~b}}$ and the anti zig-zag structure of $\mathbf{8}^{3 \mathrm{~b}}$ The helical structures arise to avoid 1-3 F-F dipolar repulsion (shown by arrows) which would occur if $\mathbf{6}$ and $\mathbf{7}$ were extended chains. This is not the case for isomer 8 where there are no such 1-3, F-F repulsions in an extended structure and thus the aliphatic chain adopts an anti-zig zag conformation.

Our interest in exploring such systems emerged from studying stereoisomers of alkane chains carrying three, ${ }^{3 f, h}$ four $^{3 \mathrm{~d}, \mathrm{~g}}, \mathrm{five}^{3 \mathrm{c}}$ and $\operatorname{six}^{6 b}$ vicinal fluorines. Some relevant structures are exemplified by compounds 6-8. We have placed a particular focus on all-syn vicinal fluoroalkanes such as $\mathbf{6}$ and $\mathbf{7}$ and find that the all-syn chains tend towards a helical arrangement of the C-F bonds, although it takes a minimum of three vicinal fluorines to induce the helical turn. This arises largely due to dipolar repulsion between the first and third fluorines if the main chain adopts the classical anti zig-zag conformation associated with an alkane chain ${ }^{11}$ as illustrated for tetrafluoro and hexafluoro alkanes $6^{3 \mathrm{~g}}$ and $7^{3 \mathrm{~b}}$ which possess four and six fluorine atoms respectively. The $\mathrm{X}$-ray structures shown in Figure 2 indicate a preferred conformation where the vicinal C$\mathrm{F}$ bonds are all gauche to each other and this helical twist propagates along the chain length. This structure is also the one which dominates in solution as indicated by NMR experiments. In the structures of $\mathbf{6}$ and $\mathbf{7}$ the dihedral angles between the vicinal F-C-C-F bonds are always close to $\sim 60^{\circ}$.

These conformations can be compared to the hexafluorodiastereoisomer $\mathbf{8}$ isomer which has the two central fluorines 'back' and does not have any $1,3-\mathrm{C}-\mathrm{F}$ repulsive interactions when the chain is extended, and thus the main chain adopts an anti zig-zag conformation as shown in Figure 2.

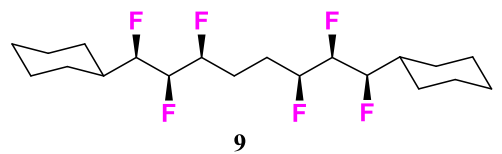

In this paper we have prepared hexafluorooctane 9 with two allsyn vicinal trifluoro sequences insulated from each other by a central non-fluorinated ethylene $\left(-\mathrm{CH}_{2} \mathrm{CH}_{2}-\right)$ insert. The objective was to explore the propensity of this chain to continue a helical conformation across the non-fluorinated carbons. The molecule was prepared with terminal cyclohexane motifs, anticipating that this would impart crystallinity, in order to facilitate X-ray structure analysis for comparison of the solid and solution state (by NMR) structures.

The synthesis of $\mathbf{9}$, as well as a discussion on the X-ray structure, the solution conformation (by NMR) and a computational analyses of preferred conformations are described below.

\section{Results and discussion}

The synthesis used to prepare hexafluoroalkane $\mathbf{9}$ is shown in Scheme 1 . The route commenced with the preparation of propargyl alcohol $\mathbf{1 1}$ via in an enantioselective zinc-acetylide addition reaction to generate cyclohexanecarboxaldehyde 10, employing the method developed by Carreira. ${ }^{12}$ This generated 11 in $88 \%$ yield and a $96 \%$ ee. Red-Al mediated reduction of alcohol 11 then afforded $E$-allylic alcohol 12 in good yield, ${ }^{13}$ and this was followed by a Sharpless epoxidation to generate the diastereoisomerically pure anti-epoxyalcohol $13 .{ }^{14} \mathrm{~A}$ stereochemical inversion of the alcohol moiety in $\mathbf{1 3}$ was required in order to generate a precursor with all of the C-O bonds syn to each other. Thus a configurational inversion, under standard Mitsunobu conditions, ${ }^{15}$ gave the para-nitrobenzoate ester 14, which was then hydrolysed to the free alcohol 15 by careful alcoholysis with $\mathrm{K}_{2} \mathrm{CO}_{3}$ in methanol. ${ }^{16}$ A sequence of TBS protection, benzyl ether hydrogenolysis, ${ }^{17}$ Dess-Martin oxidation ${ }^{18}$ to aldehyde 18 and then treatment with the ylid derived from methyl triphenylphosphonium bromide, gave terminal alkene $\mathbf{1 9}$ in an overall yield of $61 \%$ for these four steps. 

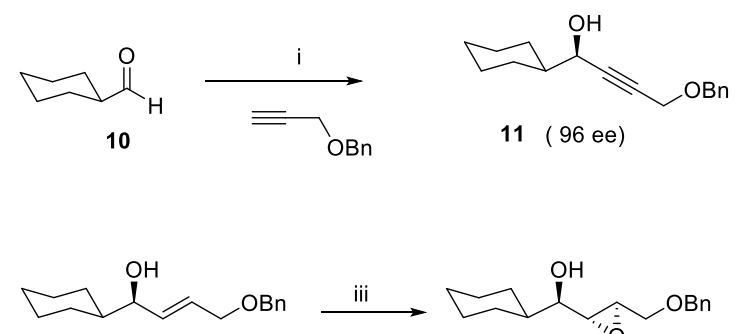<smiles>CC(C)(C)CCCCCC(=O)C(O)C1CCCCC1</smiles>

13

12
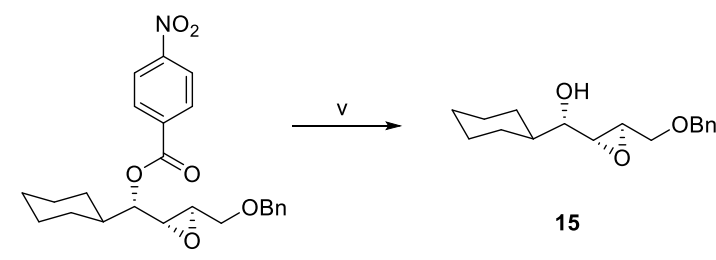

14

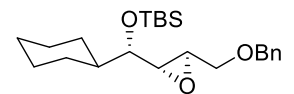

16
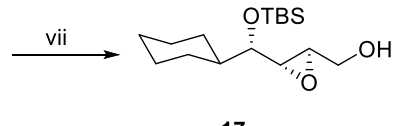

17
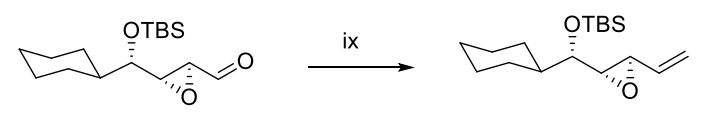

19

18

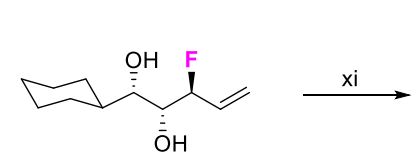

20

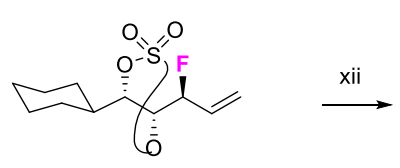

21
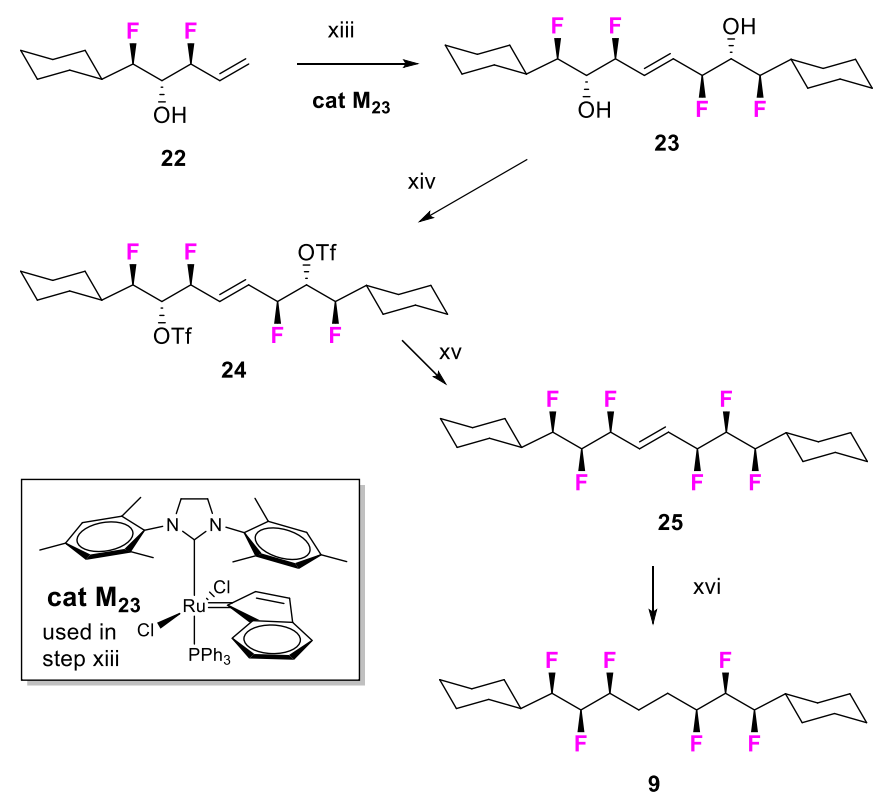

Scheme 1: i) $\mathrm{Zn}(\mathrm{OTf})_{2},(+) \mathrm{N}$-methylephedrine, Et ${ }_{3} \mathrm{~N}$, Tol., reflux, 16h, $88 \%$; ii) Red-Al, $\mathrm{THF},-40^{\circ} \mathrm{C}, 5 \mathrm{~h}, 92 \%$; iii) $\mathrm{Ti}(\mathrm{OPr}-\mathrm{i})_{4}, \quad(-)$ diisopropyltartrate, $t$-BuOOH (0.8), $4 \AA ̊ \mathrm{MS}, \mathrm{DCM},-40$ 으, $4 \mathrm{~d}, 72 \%$; iv) p-nitrobenzoic acid, DEAD, $\mathrm{PPh}_{3}, \mathrm{THF}, 0^{\circ} \mathrm{C}$ then $\mathrm{rt} 16 \mathrm{~h}, 63 \%$; v) $\mathrm{K}_{2} \mathrm{CO}_{3}$, $\mathrm{MeOH}, \mathrm{rt}, 2 \mathrm{hrs}, 97 \%$; vi) TBSOTf, Pyr, rt, 16h, 95\%; vii) $\mathrm{H}_{2}, 10 \% \mathrm{Pd} / \mathrm{C}$, $\mathrm{MeOH}, \mathrm{rt}, 16 \mathrm{~h}, 92 \%$; viii) Dess-Martin periodinane, Pyr, DCM, rt, 16h, $80 \%$; ix) MeP(Ph) ${ }_{3} \mathrm{Br}, \mathrm{KHMDS}, \mathrm{THF},-10^{\circ} \mathrm{C} ; 93 \%$; $\left.\mathrm{x}\right) 0^{\circ} \mathrm{C}, \mathrm{Et}_{3} \mathrm{~N} .3 \mathrm{HF}, 120$ ${ }^{\circ} \mathrm{C}, 16 \mathrm{~h}, 82 \%$; xi) $\mathrm{SO}_{2} \mathrm{Cl}_{2}, \mathrm{Et}_{3} \mathrm{~N}, \mathrm{DCM},-78{ }^{\circ} \mathrm{C}$ then $-10{ }^{\circ} \mathrm{C}, 85 \%$; xii) $\mathrm{Et}_{3} \mathrm{~N} .3 \mathrm{HF}, 110^{\circ} \mathrm{C}, 16 \mathrm{~h}, 18 \%$; xiii) Catalyst M23, DCM, rt, 5 day, $59 \%$; xiv) $\mathrm{Tf}_{2} \mathrm{O}, \mathrm{DCM}, \mathrm{rt}, 3 \mathrm{~d}, 95 \%$; $\mathrm{xv}$ ) $\left.\mathrm{Et}_{3} \mathrm{~N}, 3 \mathrm{HF}, \mathrm{Et}_{3} \mathrm{~N}, 50^{\circ} \mathrm{C}, 4 \mathrm{~h} ; \mathrm{xvi}\right) \mathrm{H}_{2}, 10 \%$ $\mathrm{Pd} / \mathrm{C}, \mathrm{MeOH}, \mathrm{rt}, 16 \mathrm{~h}$; (80\% steps over last two steps).

Nucleophilic deoxy-fluorination reactions were now explored to introduce the fluorines with inversions of stereochemistry. ${ }^{19}$ In the first instance nucleophilic ring-opening ( $\mathrm{Et}_{3} \mathrm{~N} .3 \mathrm{HF}$ at $140{ }^{\circ} \mathrm{C}$ ) of the epoxide ring in $\mathbf{1 9}$ led to $\mathbf{2 0}$, with the introduction of the first fluorine atom at the allylic position. ${ }^{3 a, 20}$ We then used a cyclic sulfate strategy originally developed by Sharpless, ${ }^{21}$ that we had employed previously, ${ }^{3 b, g}$ for further fluorination. Accordingly treatment with sulfuryl chloride provided cyclic sulfate $21,21(\mathrm{a})$ which was ring opened using an excess of $\mathrm{Et}_{3} \mathrm{~N} .3 \mathrm{HF}$, for the introduction of the second fluorine in 22. Ring opening occurs exclusively to the C-O-sulfate bond furthest from the first fluorine. This reaction was not so efficient and occurred in a modest yield along with various elimination products. The most straightforward strategy appeared to be to introduce the third fluorine at this stage, however $O$-triflation of difluoro alcohol 22, followed by treatment of the resultant triflate with $\mathrm{Et}_{3} \mathrm{~N} .3 \mathrm{HF}$, failed to result in a successful fluorination reaction. Therefore the direct approach was modified and alcohol 22, through its terminal alkene moiety, was subjected to a symmetrical cross-metathesis reaction employing the $\mathbf{M}_{\mathbf{2 3}}$ catalyst, developed by Nolan. ${ }^{22}$ This gave tetrafluorodiol 23 in $52 \%$ yield, and because alcohol $\mathbf{2 2}$ was enantiomerically enriched, the coupled product is generated as a single diastereoisomer. Any traces of minor diastereoisomers are removed by chromatography, resulting in both a diastereoisomerically and enantiomerically pure product. Simultaneous triflate activation of each of the free hydroxyl groups in diol $\mathbf{2 3}$ gave 24, and then subsequent substitution with fluoride anion, furnished hexafluoro alkene 25, but unfortunately the yield of this reaction was rather low (10\%). Finally, and happily, a $\mathbf{P d}$-catalysed hydrogenation of $\mathbf{2 5}$ gave the target hexafluoro alkane $\mathbf{9}$ in almost quantitative yield.

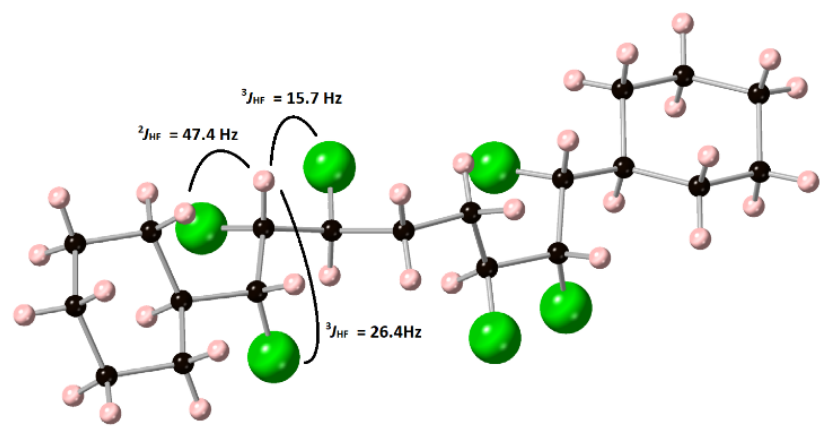

Fig 3. X-Ray structure of 9, with annotated hydrogen-fluorine NMR coupling constants derived from ${ }^{19} \mathrm{~F}-\mathrm{NMR}$. (Structure deposited as CCDC 1971579). 


\section{Solid state and NMR conformers}

Hexafluoroalkane 9 was a crystalline solid $\left(\mathrm{mp} 120^{\circ} \mathrm{C}\right)$ and a suitable crystal was subject to X-ray structure analysis. The resultant structure is shown in Figure 4. The three vicinal C-F bonds within each trifluoro motif, rotate $\sim 60^{\circ}$ to each other as they progress along the chain. The first and third C-F bonds are approximately perpendicular, relaxing any dipolar repulsion. The trifluoroalkane motifs in $\mathbf{9}$ have an orientation which almost superimposes on the structures of the first three fluoromethylene carbons of the tetrafluoro and hexafluoro all-syn isomers 5 and 6 (Figure 2). Indeed the overall conformation of the carbon chain of $\mathbf{9}$ is similar to that of the hexafluoro isomer 6 across the insulating ethylene $\left(-\mathrm{CH}_{2} \mathrm{CH}_{2}-\right)$ bridge. The sense of the helix carries onto the second trifluoro motif, thus the solid state structure indicates that helicity is maintained across the ethylene bridge. Solution state NMR is less clear. What is clear from ${ }^{19} \mathrm{~F}-\mathrm{NMR}$ is that the individual trifluoro- motifs adopt the anticipated helical conformation in solution. This is indicated by the hetero nuclear HF coupling constants, and the values for these are illustrated in Figure 3 for the central 'second' fluorine atom of the triad. The ${ }^{3} \mathrm{JFF}_{\mathrm{HF}}$ coupling constants of $26.4 \mathrm{~Hz}$ and $15.4 \mathrm{~Hz}$ are indicative ${ }^{3 \mathrm{~b}, \mathrm{~g}, 23}$ of one anti-peri-planar and one gauche relationship respectively, to the neighboring 1 and $3 \mathrm{C}-\mathrm{F}$ bonds, consistent with the solid state structure. It proved less easy however to deconvolute the coupling constants between the fluorines and protons of the trifluoro- motif and those of the ethylene bridge. This was due to signal multiplicity arising from complex second order effects between the ethylene protons (each hydrogen of the ethylene bridge is formally chemically equivalent, but magnetically nonequivalent with respect to the nuclei of the trifluoro motif), and further complexity arises due to conformational flexibility across this bridging region. There is a clear sense from NMR that there is greater conformational stability within the trifluoro- motifs than across the ethylene bridge, in solution. A computational study was carried out to gain further insight into the conformational flexibility of $\mathbf{9}$.

\section{DFT Computational study}

Given that the NMR data for $\mathbf{9}$ suggested some conformational dynamics in solution a computational analysis was carried out to explore the relative energies on candidate conformers. The relative enthalpies $(\Delta H)$ and free energies $(\Delta G)$ as well as the molecular dipole moments $(\mu)$ for various conformers were explored by DFT (B3LYP-D3/6-311+G**//B3LYP/6-31G*). ${ }^{24}$ The resultant data is summarised in Table 1 . In the first instance a comparison was explored between the all helical conformer $9 a$ (which approximates the X-ray structure) and the fully extended zig-zag conformer $9 \mathrm{~d}$.

\begin{tabular}{|l|l|l|l|l|}
\hline & $\begin{array}{l}\text { 9a } \\
\text { (kcal/mol) }\end{array}$ & $\begin{array}{l}\text { 9b } \\
\text { (kcal/mol) }\end{array}$ & $\begin{array}{l}\text { 9c } \\
\text { (kcal/mol) }\end{array}$ & $\begin{array}{l}9 d \\
(\mathrm{kcal} / \mathrm{mol})\end{array}$ \\
\hline $\begin{array}{l}\Delta H \\
\text { (CPCM) }\end{array}$ & 0.36 & 0.0 & 2.09 & 4.64 \\
\hline $\begin{array}{l}\Delta G \\
\text { (CPCM) }\end{array}$ & 0.41 & 0.0 & 1.84 & 4.13 \\
\hline
\end{tabular}

\begin{tabular}{|c|l|l|l|l|}
\hline $\begin{array}{c}\mu \\
(\mathrm{CPCM})^{b}\end{array}$ & $7.11 \mathrm{D}$ & $1.01 \mathrm{D}$ & $6.13 \mathrm{D}$ & $9.79 \mathrm{D}$ \\
\hline
\end{tabular}

${ }^{a}$ B3LYP-D3(CPCM)/6-311+G** level, in $\mathrm{kcal} / \mathrm{mol}$ relative to $\mathbf{b}$ (solvent model using the parameters for $\mathrm{CH}_{2} \mathrm{Cl}_{2}$ ).

Table1: Relative enthalpies $\left(\Delta H^{298 K}\right)$ and free energies $\left(\Delta G^{298 K}\right)$ of conformers $\mathbf{9 a}$ - $9 \mathrm{~d}$ in a conductor-like polarisable continuum model
(CPCM), modelling dichloromethane. ${ }^{a}$ (In italics: computed molecular dipole moment $\mu$ [in Debey (D)] in the continuum.

These experiments found that the optimised fully extended zigzag conformer $9 \mathrm{~d}$ was over $4.0 \mathrm{kcal} / \mathrm{mol}$ higher in energy than the helical conformer 9 a. There are two 1,3-difluoro repulsions in $\mathbf{9 d}$ which contribute significantly to raising the energy of this conformer over 9a, where there are no such interactions. It is interesting that helical conformer 9 a retains a high molecular dipole, only a little lower than that of 9d (9a; $\mu=7.11 \mathrm{D} \& 9 \mathrm{~d} ; \mu$ $=9.79 \mathrm{D})$, despite being significantly lower in energy. This arises because all six fluorines are on one side of the molecule, in this relaxed conformation, most clearly illustrated by viewing 9a along its longitudinal axis as shown in Figure 4. There are no fluorines on the central ethylene bridge; if there were, those

$9 a$
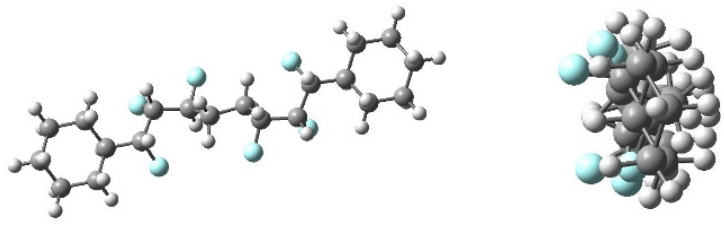

Side view (similar to X-ray) longitudinal view of 9a

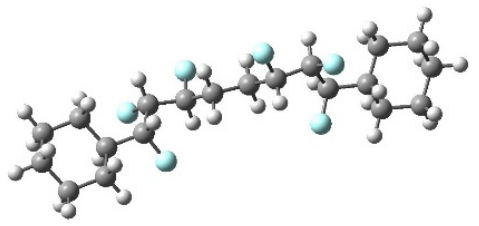

helical-anti-helical structure (lowest energy conformer)

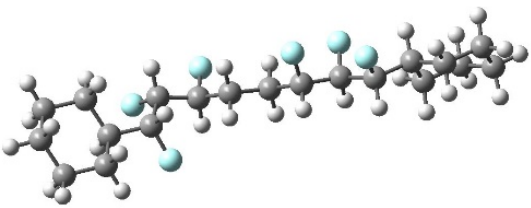

9c

helical-partial anti-zig-zag structure

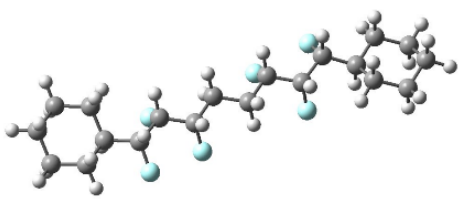

9d

full anti-zig-zag structure (highest energy structure)

Fig. 4 Computed (minimised) conformers for 9a-9d. Relative energies are given in Table 1.

fluorines would locate on the opposite face and reduce the overall molecular dipole. Eg consider the much lower calculated molecular dipole for the all-helical conformation for the virtual all-syn octafluoroalkane 26a ( $\mu=2.51 \mathrm{D})$ illustrated in Figure 6. In order to probe the contributions of the 1,3-difluoro 
repulsions due to $\mathrm{C}-\mathrm{F}$ eclipsing interactions, conformations were set such that either one (9c), or both (9b) of the flanking trifluoro motifs of anti zig-zag 9d were relaxed into a helical conformation. In each case the energy of these conformers reduced sequentially (Table 1 ), and $\mathbf{9 b}$ with helical trifluoromotifs and an antiperiplanar conformation across the acetylene bridge became the lowest energy conformer of all. This conformer also had a very low molecular dipole (9b; $\mu=$ $1.01 \mathrm{D})$ and is more stable $(\Delta \mathrm{H}=-0.36 \mathrm{kcal} / \mathrm{mol})$ than the fully helical structure 9a. Preliminary calculations in the gas phase (data not shown) indicated that the energy difference between the lowest energy conformer $\mathbf{9 b}$ and all of the higher energy conformers reduced significantly in a conductor-like polar continuum model (CPCM). Table 1 reports the energies at a dielectric constant mimicking dichloromethane. The data suggests that in solvents more polar than dichloromethane then particularly, conformers $\mathbf{9 a}$ and $\mathbf{9 b}$ will interconvert in solution as they become closer in energy $\left(\Delta \mathrm{H}=0.36 \mathrm{kcal} \mathrm{mol}^{-1} ; \Delta \mathrm{G}=0.41\right.$ kcal mol-1)

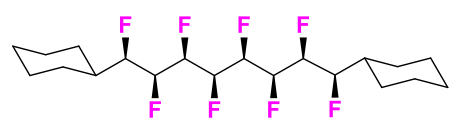

26

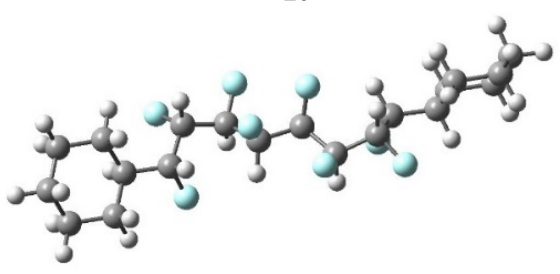

$26 a$

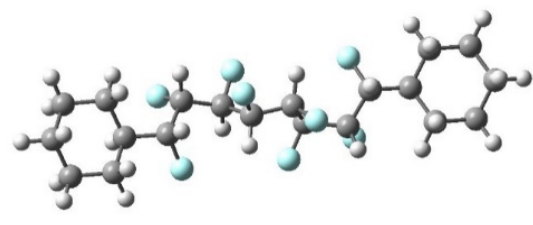

$26 b$

$\begin{array}{ll}\text { helical 26a } & \text { helical-anti-helical 26b } \\ (0.0 \mathrm{kcal} / \mathrm{mol}) & (+4.1 \mathrm{kcal} / \mathrm{mol}) \\ (\mu=3.87 \mathrm{D}) & (\mu=0.72 \mathrm{D})\end{array}$

Fig. 5. DFT computed conformers (B3LYP-D3(CPCM)/6-311+G** level) of virtual all-syn octafluoroalkane 26 . The fully helical structure 26a is significantly more stable (by $\Delta \mathrm{H}=-4.1 \mathrm{kcal} / \mathrm{mol}$ ) than the helical-anti-helical structure $\mathbf{2 6 b}$, indicating a preference for helicity with a complete sequence of fluorines.

As a virtual experiment, the energy of two conformers of the allsyn octafluoro alkane 26, with two vicinal fluorines now positioned on the ethylene bridge were evaluated. The fully helical structure $26 \mathrm{a}$ is significantly more stable (by $\Delta \mathrm{H}=-4.1$ $\mathrm{kcal} / \mathrm{mol}$ ) than 26b, the fully fluorinated equivalent to the lowest energy conformer $\mathbf{9 b}$. This data is summarised in Figure 6 . Notably the molecular dipole of $26 \mathrm{a}(\mu=3.87 \mathrm{D})$ is very much reduced relative to $9 \mathrm{a}(\mu=7.11 \mathrm{D})$, indicating that populating the full helix with fluorines introduces mid-chain C-F bonds which oppose the dipoles of the flanking trifluoro motifs, and reducing the overall molecular dipole. Thus a continuous chain of syn-fluorines re-establishes the dominance of the helical arrangement, but reduces its polarity. Although the removal of the two central fluorines results in an increased conformational ambivalence across the ethylene bridge, it may actually offer advantages as a design feature to generate polar conformers in solution for applications such as liquid crystal materials where retaining polarity is an important performance property, or as a motif for polar polymers.

In conclusion, we have synthesised $\mathbf{9}$ an all-syn hexafluorinated alkane chain with an ethylene spacer. The solid state X-ray structure of 9 demonstrated the integrity of a helical twist across the ethylene bridge, however the solution conformation and computational studies suggest that the removal of fluorines introduces a flexible region which is conformationally disordered. A feature to emerge from this study is that removal of two fluorines from the continuous sequence of fluorines results in low energy conformers in solution, which have high molecular dipoles, and thus populations of such conformers will contribute polarity in solution.

\section{Experimental}

Synthesis protocols are described below;

(R)-3-Benzyloxy-1-cyclohexylprop-2-yn-1-ol (11):

Toluene $(20 \mathrm{~mL})$ and dry triethylamine $(3.14 \mathrm{~mL}, 27.8 \mathrm{mmol})$ were sequentially added to a mixture of $\mathrm{Zn}(\mathrm{OTf})_{2}(9.3 \mathrm{~g}, 25.3$ $\mathrm{mmol})$ and (+)- $\mathrm{N}$-methylephedrine $(5 \mathrm{~g}, 27.8 \mathrm{mmol}$ ) under an argon atmosphere. After stirring at $23{ }^{\circ} \mathrm{C}$ for $2 \mathrm{~h}$, the $O$-benzyl proparglic alcohol (4.43 g, $30.4 \mathrm{mmol}$ ) was added in one portion. After $15 \mathrm{~min}$. stirring, cyclohexanecarboxaldehyde $\mathbf{1 0}$ $(2.84 \mathrm{~g}, 25.32 \mathrm{mmol})$ was added in one portion to the reaction mixture and was further stirred for $16 \mathrm{~h}$ at ambient temperature. Sat. aq $\mathrm{NH}_{4} \mathrm{Cl}(50 \mathrm{ml})$ was added to the reaction and the organics were extracted into diethyl ether. The combined organic extracts were washed with brine $(100 \mathrm{~mL})$, dried over $\mathrm{MgSO}_{4}$, filtered and concentrated under reduced pressure. The residue was subjected to silica gel chromatography (petroleum ether:EtOAc 9:1) to afford $\mathbf{1 1}$ (6.73 g, 88\%) as a colourless oil $[\alpha]_{\mathrm{D}}=+21\left(\mathrm{c}=1, \mathrm{CHCl}_{3}\right)$. H-NMR $\left(\mathrm{CDCl}_{3}, 300 \mathrm{MHz}\right): \delta$ 7.30-7.36 (m, 5H), $4.60(\mathrm{~s}, 2 \mathrm{H}), 4.22(\mathrm{~s}, 2 \mathrm{H})$, 4.20-4.23 (m, $1 \mathrm{H}), 4.20-4.23(\mathrm{~m}, 1 \mathrm{H}), 1.77-1.93(\mathrm{~m}, 5 \mathrm{H}), 1.66-$ $1.71(\mathrm{~m}, 1 \mathrm{H}), 1.52-1.61(\mathrm{~m}, 1 \mathrm{H}), 1.3-1.32(\mathrm{~m}, 5 \mathrm{H}) ;{ }^{13} \mathrm{C} N M R$ $\left(\mathrm{CDCl}_{3}, 75 \mathrm{MHz}\right): \delta 137.4,128.4,128.1,127.9,86.7,81.5,71.6$, 67.2, 57.4, 44.0, 28.5, 28.1, 26.3, 25.80; MS (ESI, +ve) $\mathrm{m} / \mathrm{z} 281$ $\left(\mathrm{M}+\mathrm{Na}^{+}, 100 \%\right)$, HRMS calculated for $\mathrm{C}_{17} \mathrm{H}_{22} \mathrm{O}_{2} \mathrm{Na}\left[\mathrm{M}+\mathrm{Na}^{+}\right]$ 281.1517, found 281.1512.

\section{(R)-3-Benzyloxy-1-cyclohexylprop-2-en-1-ol (12):}

A solution of sodium bis(2-methoxyethoxy)aluminumhydride (Red-Al ${ }^{\circledast}, 65 \%$ in toluene, $31.1 \mathrm{~mL}, 100.0 \mathrm{mmol}$ ) was slowly added to a solution of $\mathbf{1 1}(12.9 \mathrm{~g}, 50.0 \mathrm{mmol})$ in dry THF (282 $\mathrm{mL}$ ) at $-40^{\circ} \mathrm{C}$ under an argon atmosphere. The reaction mixture 
was allowed to stir while warming from $-40{ }^{\circ} \mathrm{C}$ to $0{ }^{\circ} \mathrm{C}$ over $4 \mathrm{~h}$, and was then carefully quenched by the slow addition of a sat. aq. $\mathrm{NH}_{4} \mathrm{Cl}(50 \mathrm{~mL})$ and diluted with EtOAc $(100 \mathrm{~mL})$. The aqueous phase was extracted into EtOAc and the combined organic extracts were dried over $\mathrm{MgSO}_{4}$, filtered and solvents were removed under reduced pressure. The product was purified over silica gel (petroleum ether: $\mathrm{Et}_{2} \mathrm{O}$ 8:2), providing 12 (11.95 g, $92 \%)$ as pale yellow oil $[\alpha]_{\mathrm{D}}=+19.3\left(\mathrm{c}=1, \mathrm{CHCl}_{3}\right)$. H-NMR $\left(\mathrm{CDCl}_{3}\right.$, $300 \mathrm{MHz}): \delta$ 7.29-7.38 (m, 5H), 5.78-5.80 (m, 2H), $4.55(\mathrm{~s}, 2 \mathrm{H})$, $4.06(\mathrm{~d}, 2 \mathrm{H}, J=3.9 \mathrm{~Hz}), 3.88(\mathrm{br} \mathrm{s}, 1 \mathrm{H}), 1.67-1.91(\mathrm{~m}, 6 \mathrm{H}), 1.36-$ $1.49(\mathrm{~m}, 1 \mathrm{H}), 0.94-1.32(\mathrm{~m}, 4 \mathrm{H}) ;{ }^{13} \mathrm{C} \mathrm{NMR}\left(\mathrm{CDCl}_{3}, 75 \mathrm{MHz}\right): \delta$ 138.2, 134.7, 128.4, 128.0, 127.7, 127.6, 76.8, 72.2, 70.2, 43.5, 28.8, 28.4, 26.4, 26.1, 26.1; HRMS (ES, +ve) $\mathrm{m} / \mathrm{z}$ calcd for $\mathrm{C}_{17} \mathrm{H}_{24} \mathrm{O}_{2} \mathrm{Na}\left[\mathrm{M}+\mathrm{Na}^{+}\right]$283.1674, found 283.1672.

Sharpless epoxidation: (1R, 2R, 3S)-4-Benzyloxy-1-cyclohexyl2,3-epoxybutanol (13);

A flask containing $4 \AA$ powdered and activated molecular sieves $(3 \mathrm{~g})$ in dichloromethane $(200 \mathrm{~mL})$ was cooled to $-20{ }^{\circ} \mathrm{C}$ under an nitrogen. Titanium tetra isopropoxide $(2.52 \mathrm{~mL}, 8.63 \mathrm{mmol})$ and (+)-diisopropyl tartrate $(2.37 \mathrm{~mL}, 11.25 \mathrm{mmol})$ were added sequentially with stirring, and then tert-butylhydroperoxide (3.55 mL, 5.5 M in decane, $19.50 \mathrm{mmol}$ ) was slowly added. After 30 min stirring at $-20^{\circ} \mathrm{C}$, a solution of E-alkene 12 ( $2.24 \mathrm{~g}, 8.63$ $\mathrm{mmol}$ ) in dichloromethane was added dropwise. The mixture was stirred for an additional $3.5 \mathrm{hrs}$ at $-20^{\circ} \mathrm{C}$. Sodium sulfate $(5$ $\mathrm{mL}$, saturated aqueous) was added and the mixture was diluted with dichloromethane $(100 \mathrm{~mL})$. The resulting mixture was then stirred vigorously for $16 \mathrm{~h}$ at $\mathrm{rt}$. The resulting slurry was filtered and the organic layer was dried over $\mathrm{MgSO}_{4}$. The mixture was purified by flash chromatography $\left(\mathrm{CH}_{2} \mathrm{Cl}_{2} / \mathrm{AcOEt}\right.$ $100 / 0 \rightarrow 80 / 20)$, providing derivative 13 as a white solid (1.71 $\mathrm{g}$, $72 \%)[\alpha]_{\mathrm{D}}=+7.1\left(\mathrm{c}=1, \mathrm{CHCl}_{3}\right) ;$ m.p. $=49-50{ }^{\circ} \mathrm{C} ;{ }^{1} \mathrm{H} \mathrm{NMR}\left(\mathrm{CDCl}_{3}\right.$, $300 \mathrm{MHz}): \delta 7.27-7.35(\mathrm{~m}, 5 \mathrm{H}), 4.61\left(\mathrm{~d}, J_{A B}=12.1 \mathrm{~Hz}, 1 \mathrm{H}\right), 4.52$ $\left(\mathrm{d}, J_{A B}=12.1 \mathrm{~Hz}, 1 \mathrm{H}\right), 3.80(\mathrm{dd}, J=11.6,2.8 \mathrm{~Hz}, 1 \mathrm{H}), 3.63(\mathrm{~m}, 1 \mathrm{H})$, $3.50(\mathrm{dd}, J=11.6,5.7 \mathrm{~Hz}, 1 \mathrm{H}), 3.27-3.30(\mathrm{~m}, 1 \mathrm{H})$, ), $1.96(\mathrm{brs}, 1 \mathrm{H})$, 1.66-1.82 (m, 6H), 1.48-1.57 (m, 1H), 1.11-1.30 (m, 4H); ${ }^{13} \mathrm{C} \mathrm{NMR}$ $\left(\mathrm{CDCl}_{3}, 75 \mathrm{MHz}\right): \delta 137.8(\mathrm{C}), 128.5(\mathrm{CH}), 127.9(\mathrm{CH}), 127.7,73.3$, $72.3,69.7,56.8,53.5,41.5,28.9,28.1,26.4,26.2,26.1$; HRMS (ES, +ve) $\mathrm{m} / z$ calcd for $\mathrm{C}_{17} \mathrm{H}_{24} \mathrm{O}_{3} \mathrm{Na}\left[\mathrm{M}+\mathrm{Na}^{+}\right] 299.1623$, found 299.1646.

Mitsunobu Reaction: (1R, 2R, 3S)-4-Benzyloxy-1-cyclohexyl2,3-epoxybutyl 4-nitrobenzoate (14);

Diisopropyl azodicarboxylate $(15.72 \mathrm{~mL}, 86.3 \mathrm{mmol})$ was slowly added to a stirred solution of 13 (15 g, $54 \mathrm{mmol}), \mathrm{PPh}_{3}(22.5 \mathrm{~g}$, $86.3 \mathrm{mmol})$ and $p$-nitrobenzoic acid $(19.2 \mathrm{~g}, 80.9 \mathrm{mmol})$ in THF $(200 \mathrm{~mL})$ at $-30^{\circ} \mathrm{C}$. The mixture was stirred at $-30^{\circ} \mathrm{C}$ for $2 \mathrm{~h}$ and was then allowed to warm to $\mathrm{rt}$ and left stirring for $16 \mathrm{~h}$. The reaction mixture was concentrated and purified over silica gel (petrol ether /AcOEt 100/0 $\rightarrow 80 / 20$ ) to obtain 14 (17.9 g, 78\%) as a white solid $[\alpha]_{\mathrm{D}}=+11.6\left(\mathrm{c}=1, \mathrm{CHCl}_{3}\right): \mathrm{Mp}=118-119{ }^{\circ} \mathrm{C} ;{ }^{1} \mathrm{H}$ $\operatorname{NMR}\left(\mathrm{CDCl}_{3}, 300 \mathrm{MHz}\right): \delta 8.30\left(\mathrm{~d}, J_{\mathrm{AB}}=9.0 \mathrm{~Hz}, 2 \mathrm{H}\right), 8.23\left(\mathrm{~d}, J_{\mathrm{AB}}=\right.$ $9.0 \mathrm{~Hz}, 2 \mathrm{H}), 7.28-7.37(\mathrm{~m}, 5 \mathrm{H}), 4.83(\mathrm{t}, \mathrm{J}=6.7 \mathrm{~Hz}, 1 \mathrm{H}), 4.59(\mathrm{~d}$, $\left.J_{A B}=12.0 \mathrm{~Hz}, 1 \mathrm{H}\right), 4.55\left(\mathrm{~d}, J_{\mathrm{AB}}=12.0 \mathrm{~Hz}, 1 \mathrm{H}\right), 3.77(\mathrm{dd}, J=11.7$, $3.1 \mathrm{~Hz}, 1 \mathrm{H}$ ), 3.54 (dd, $J=11.6,5.1 \mathrm{~Hz}, 1 \mathrm{H}), 3.20$ (dd, $J=6.7,2.1$ $\mathrm{Hz}, 1 \mathrm{H}), 3.13-3.16(\mathrm{~m}, 1 \mathrm{H}), 1.65-1.92(\mathrm{~m}, 6 \mathrm{H}), 0.83-1.32(\mathrm{~m}, 5 \mathrm{H})$;
${ }^{13} \mathrm{C} \mathrm{NMR}\left(\mathrm{CDCl}_{3}, 75 \mathrm{MHz}\right): \delta 164.0,150.5,137.6,135.6,130.8$, 128.4, 127.8, 127.6, 123.5, 79.0, 73.3, 69.1, 55.7, 55.1, 40.2, 28.8, 28.7, 26.1, 25.8, 25.7; HRMS (ESI, +ve) $\mathrm{m} / z$ calculated for $\mathrm{C}_{24} \mathrm{H}_{27} \mathrm{NO}_{6} \mathrm{Na}[\mathrm{M}+\mathrm{Na}+]$ 448.1736, found 448.1728 .

(1R, 2R, 3S)-4-Benzyloxy-1-cyclohexyl-2,3-epoxybutanol (15); $\mathrm{K}_{2} \mathrm{CO}_{3}(7 \mathrm{~g}, 50.5 \mathrm{mmol})$ was added to a solution of 14 (12.5 g, $29.4 \mathrm{mmol})$ in $\mathrm{MeOH}(70 \mathrm{~mL})$ at room temperature. After $1 \mathrm{~h}$ stirring, the reaction mixture was diluted with dichloromethane $(300 \mathrm{~mL})$, washed with water $(300 \mathrm{~mL})$, dried over $\mathrm{MgSO}_{4}$ and concentrated under reduced pressure. The residue was purified over silica gel (petrol ether/ether 10:0 $\rightarrow 8: 2$ ), providing derivative 15 as a white solid solid $(7.1 \mathrm{~g}, 87.4 \%),[\alpha]_{\mathrm{D}}=+15.4$ ( $\mathrm{c}=1, \mathrm{CHCl}_{3}$ ); m.p. $=45-46^{\circ} \mathrm{C}$. IR (neat) vmax (cm-1) 3390, 2854, $1452,1200,1145,1097,737,698 ; 1 \mathrm{H} \mathrm{NMR}\left(\mathrm{CDCl}_{3}, 300 \mathrm{MHz}\right): \delta$ 7.30-7.38 (m, 5H), $4.60\left(\mathrm{~d}, J_{A B}=12 \mathrm{~Hz}, 1 \mathrm{H}\right), 4.55\left(\mathrm{~d}, J_{A B}=12 \mathrm{~Hz}\right.$, $1 \mathrm{H}), 3.77(\mathrm{dd}, J=11.7,3.1 \mathrm{~Hz}, 1 \mathrm{H}), 3.50(\mathrm{dd}, J=11.6,5.6 \mathrm{~Hz}, 1 \mathrm{H})$, 3.14-3.24 (m, 2H), $2.97(\mathrm{dd}, J=2.3,5.1 \mathrm{~Hz}, 1 \mathrm{H}), 1.65-2.00(\mathrm{~m}$, $5 \mathrm{H}), 1.48-1.59(\mathrm{~m}, 1 \mathrm{H}), 0.83-1.32(\mathrm{~m}, 5 \mathrm{H}) ;{ }^{13} \mathrm{C} \mathrm{NMR}\left(\mathrm{CDCl}_{3}, 75\right.$ $\mathrm{MHz}): \delta 137.8(\mathrm{C}), 128.4(\mathrm{CH}), 127.8(\mathrm{CH}), 127.7,75.0,73.3$, 69.6, 57.4, 55.4, 42.2, 28.7, 28.6, 26.3, 26.0, 25.9; HRMS (ESI, +ve) $\mathrm{m} / z$ calcd for $\mathrm{C}_{17} \mathrm{H}_{24} \mathrm{O}_{3} \mathrm{Na}\left[\mathrm{M}+\mathrm{Na}^{+}\right] 299.1623$, found 299.1615 .

(1R, 2R, 3S)-1-tert-Butyldimethylsiloxy-4-benzyloxy-1cyclohexyl-2,3-epoxybutane (16);

TBSOTf $(5.36 \mathrm{ml}, 23.38 \mathrm{mmol})$ was slowly added to a solution of the epoxy alcohol $15(5 \mathrm{~g}, 18.1 \mathrm{mmol})$ in dry pyridine $(30 \mathrm{~mL})$ at $0{ }^{\circ} \mathrm{C}$ under an argon atmosphere. The reaction mixture was allowed to warm gradually to room temperature and stirring was continued for $16 \mathrm{~h}$. The mixture was diluted with diethyl ether $(100 \mathrm{~mL})$ and was washed with $10 \%$ aq $\mathrm{CuSO}_{4}(50 \mathrm{~mL})$. The aqueous layer was extracted into diethyl ether $(50 \mathrm{~mL} \times 2)$, and the combined organic extracts were washed with brine $(100 \mathrm{~mL})$ and dried over $\mathrm{MgSO}_{4}$. After filtration, the solvent was removed under reduced pressure and the resulting product was purified over silica gel (petroleum ether/EtOAc 9:1) to give 16 as a colourless oil (6.7 g, 95\%); ${ }^{1} \mathrm{H} \mathrm{NMR}\left(300 \mathrm{MHz}, \mathrm{CDCl}_{3}\right)$ ठ 7.28-7.37 $(\mathrm{m}, 5 \mathrm{H}), 4.60\left(\mathrm{~d}, J_{A B}=11.9 \mathrm{~Hz}, 1 \mathrm{H}\right), 4.55\left(\mathrm{~d}, J_{A B}=11.9 \mathrm{~Hz}, 1 \mathrm{H}\right)$, $3.75(\mathrm{dd}, J=11.4,3.1 \mathrm{~Hz}, 1 \mathrm{H}), 3.47(\mathrm{dd}, J=11.4,5.9 \mathrm{~Hz}, 1 \mathrm{H})$, 3.00-3.04 (m, 2H), $2.86(\mathrm{dd}, J=7.4,2.3 \mathrm{~Hz}, 1 \mathrm{H}), 1.64-1.85(\mathrm{~m}$, $5 \mathrm{H}), 1.45-1.52(\mathrm{~m}, 1 \mathrm{H}), 1.01-1.271(\mathrm{~m}, 5 \mathrm{H}), 0.92(\mathrm{~s}, 9 \mathrm{H}), 0.13(\mathrm{~s}$, $3 \mathrm{H}), 0.05(\mathrm{~s}, 3 \mathrm{H}) ;{ }^{13} \mathrm{C} \mathrm{NMR}\left(\mathrm{CDCl}_{3}, 75 \mathrm{MHz}\right): \delta 138.0,128.4$, 127.8, 127.7, 78.5, 73.3, 70.3, 58.6, 55.6, 43.0, 29.2, 28.8, 26.5, 26.3, 26.2, 26.0, 18.3, -4.2, -5.1; HRMS (ESI, +ve) $\mathrm{m} / \mathrm{z}$ calcd for $\mathrm{C}_{23} \mathrm{H}_{38} \mathrm{O}_{3} \mathrm{SiNa}\left[\mathrm{M}+\mathrm{Na}^{+}\right]$413.2488, found 413.2483.

(1R, 2R, 3S)-4-tert-Butyldimethylsiloxy-4-cyclohexyl-2,3epoxybutanol (17);

Palladium (10\%) on activated carbon ( $0.5 \mathrm{~g}$ ) was added to a solution of $16(8 \mathrm{~g}, 20.5 \mathrm{mmol})$ in EtOAc $(50 \mathrm{~mL})$. After $5 \mathrm{~h}$ stirring at room temperature under a hydrogen atmosphere, the mixture was filtered through a pad of celite and concentrated under reduced pressure. The residue was purified over silica gel (petroleum ether: $\mathrm{Et}_{2} \mathrm{O} 9: 1$ to 8:2) to give 17 as a colourless oil (5.7 g, 91\%); ${ }^{1} \mathrm{H} \mathrm{NMR}\left(300 \mathrm{MHz}, \mathrm{CDCl}_{3}\right) \delta 3.94$ (dd, $J=12.7,2.2 \mathrm{~Hz}, 1 \mathrm{H}$ ), $3.62(\mathrm{dd}, J=12.7,4.0 \mathrm{~Hz}, 1 \mathrm{H}), 2.95-3.05$ 
(m, 3H), 1.64-1.85 (m, 5H), 1.45-1.51 (m, 1H), 0.99-1.27 (m, 5H), $0.91(\mathrm{~s}, 9 \mathrm{H}), 0.10(\mathrm{~s}, 3 \mathrm{H}), 0.04(\mathrm{~s}, 3 \mathrm{H}) ;{ }^{13} \mathrm{C}$ NMR $\left(75 \mathrm{MHz}, \mathrm{CDCl}_{3}\right)$ $\delta$ 78.4, 61.3, 58.3, 57.0, 42.9, 29.1, 28.8, 26.4, 26.2, 26.1, 25.9, 18.2, -4.2, -5.1 ; HRMS (ESI, +ve) $\mathrm{m} / z$ calculated for $\mathrm{C}_{16} \mathrm{H}_{32} \mathrm{O}_{3} \mathrm{SiNa}$ $\left[\mathrm{M}+\mathrm{Na}^{+}\right]$323.2018, found 323.2011.

\section{(1R, 2R, 3S)-4-tert-Butyldimethylsiloxy-4-cyclohexyl-2,3-} epoxybutanal (18);

Pyridine $(5.69 \mathrm{~mL}, 68.69 \mathrm{mmol}$ ) was added to a solution of the epoxyalcohol $17(5.5 \mathrm{~g}, 18.32 \mathrm{mmol})$ in dichloromethane (50 $\mathrm{mL}$ ) at $0{ }^{\circ} \mathrm{C}$ under an argon atmosphere. After 15 min stirring at $0^{\circ} \mathrm{C}$, a solution of DMP $(11.7 \mathrm{~g}, 27.5 \mathrm{mmol})$ in dichloromethane $(50 \mathrm{~mL})$ was added and the mixture was stirred at $0^{\circ} \mathrm{C}$ temperature, before it was allowed to warm to room temperature. The resultant mixture was stirred for $16 \mathrm{~h}$ before dilution with diethyl ether and partial concentration using a rotary evaporator. The residue was diluted with diethyl ether $(100 \mathrm{~mL})$, and the precipitate removed by extraction with sat. aq. $\mathrm{NaHCO}_{3}(100 \mathrm{~mL} \times 2)$. The organic layer was washed with water $(100 \mathrm{~mL})$ and then brine $(100 \mathrm{~mL})$. The combined aqueous washings were back-extracted with diethyl ether $(50 \mathrm{~mL})$ and the organic extracts were dried over $\mathrm{MgSO}_{4}$, filtered and concentrated. Flash chromatography (petroleum ether:ether 9:1) provided 18 as a colourless oil (4.4 g, 80\%); ${ }^{1} \mathrm{H}$ NMR (300 $\left.\mathrm{MHz} \mathrm{CDCl}_{3}\right): \delta 9.01(\mathrm{~d}, J=6.4 \mathrm{~Hz}, 1 \mathrm{H}), 3.26(\mathrm{dd}, J=7.1,2.1 \mathrm{~Hz}$, $1 \mathrm{H}), 3.21$ (dd, $J=6.4,2.1 \mathrm{~Hz}, 1 \mathrm{H}$ ), 3.08 (dd, $J=6.9,5.9 \mathrm{~Hz}, 1 \mathrm{H}$ ), $1.42-1.81(\mathrm{~m}, 6 \mathrm{H}), 0.91-1.29(\mathrm{~m}, 5 \mathrm{H}), 0.93(\mathrm{~s}, 9 \mathrm{H}), 0.12(\mathrm{~s}, 3 \mathrm{H})$, 0.05 (s, 3H); ${ }^{13} \mathrm{C} \mathrm{NMR}\left(75 \mathrm{MHz} \mathrm{CDCl}_{3}\right.$ ) : $\delta$ 198.0, 77.7, 58.8, 58.1, 43.0, 29.2, 28.8, 26.5, 26.3, 26.2, 26.0, 18.6, -4.0, -4.6; HRMS (ESI, +ve) $\mathrm{m} / z$ calculated for $\mathrm{C}_{16} \mathrm{H}_{30} \mathrm{O}_{3} \mathrm{SiNa}[\mathrm{M}+\mathrm{Na}+]$ 321.1862, found 321.1860 .

(1R, 2R, 3S)-5-tert-Butyldimethylsiloxy-5-cyclohexyl-3,4epoxypentene (19);

A solution of KHMDS (20.0 mL, $20.0 \mathrm{mmol}, 1 \mathrm{M}$ in THF) was added dropwise to a suspension of dried methyltriphenylphosphonium bromide $(8.15 \mathrm{~g}, 22.82 \mathrm{mmol})$ in THF $(100 \mathrm{~mL})$ at $-10{ }^{\circ} \mathrm{C}$ and under argon atmosphere. The resulting mixture was stirred at room temperature for $30 \mathrm{~min}$ and was then re-cooled to $-10^{\circ} \mathrm{C}$. A solution of aldehyde 18 (3.4 $\mathrm{g}, 11.4 \mathrm{mmol})$ in THF $(50 \mathrm{~mL})$ was added via cannula, and the resulting mixture was stirred at $-10{ }^{\circ} \mathrm{C}$ for $1 \mathrm{hr}$ and was then warmed to ambient temperature. After $18 \mathrm{~h}$ stirring, the suspension was filtered through celite (THF wash), and the yellow filtrate was concentrated under reduced pressure. The residue was purified by silica gel chromatography (petroleum ether: ether 98:2) to afford 19 as light yellow oil ( $3.1 \mathrm{~g}, 92 \%) ; \delta$ 5.43-5.60 (m, 2H), $5.27(\mathrm{dd}, J=9.8,2.0,0.5 \mathrm{~Hz}, 1 \mathrm{H}), 3.15$ (dd, $J$ $=7.5,2.2 \mathrm{~Hz}, 1 \mathrm{H}$ ), 3.00 (dd, $J=7.4,6.4 \mathrm{~Hz}, 1 \mathrm{H}), 2.86$ (dd, $J=7.4$, $2.2 \mathrm{~Hz}, 1 \mathrm{H}), 1.82-1.87$ (d brs, $1 \mathrm{H}), 1.58-1.76(\mathrm{~m}, 4 \mathrm{H}), 1.43-1.52$ $(\mathrm{m}, 1 \mathrm{H}), 0.96-1.24(\mathrm{~m}, 5 \mathrm{H}), 0.91(\mathrm{~s}, 9 \mathrm{H}), 0.12(\mathrm{~s}, 3 \mathrm{H}), 0.04(\mathrm{~s}, 3 \mathrm{H})$; ${ }^{13} \mathrm{C} \mathrm{NMR}\left(75 \mathrm{MHz}, \mathrm{CDCl}_{3}\right): \delta 135.2,119.5,78.7,62.7,57.5,42.9$, 29.0, 28.9, 26.5, 26.3, 26.2, 26.0, 18.3, -4.2, -5.0; HRMS (ESI, + ve) $\mathrm{m} / \mathrm{z}$ calcd for $\mathrm{C}_{17} \mathrm{H}_{32} \mathrm{O}_{2} \mathrm{SiNa}\left[\mathrm{M}+\mathrm{Na}^{+}\right] 319.2069$, found 319.2074 .

\section{$(1 R, 2 R, 3 S)-5-C y c l o h e x y l-4,5-d i h y d r o x y-3-f l u o r o p e n t-1-e n e$} (20);

Vinyloxirane $19(2.1 \mathrm{~g}, 7.1 \mathrm{mmol})$ and a magnetic bar were placed in a teflon flask equipped with condenser and the flask was evacuated and kept under argon atmosphere. Triethylamine trihydrofluoride ( $3 \mathrm{~mL}, 18.4 \mathrm{mmol}$ ) was added, and the reaction mixture was stirred at $110^{\circ} \mathrm{C}$ for $16 \mathrm{~h}$, and was then cooled to $0{ }^{\circ} \mathrm{C}$. The reaction mixture was diluted with EtOAc $(100 \mathrm{~mL})$, washed with ice-cold aq. $\mathrm{NaHCO}_{3}(100 \mathrm{~mL})$, and the aqueous phase was back-extracted with EtOAc $(50 \mathrm{~mL} \times 2)$. The combined organic extracts were dried over $\mathrm{MgSO}_{4}$, filtered and concentrated. The residue was purified over silica gel (hexane/EtOAc 85:15) to afford fluorohydrin 20 as a white solid $(1.1 \mathrm{~g}, 82 \%) ;$ m.p. $=86-87^{\circ} \mathrm{C},{ }^{1} \mathrm{H}$ NMR $\left(300 \mathrm{MHz}, \mathrm{CDCl}_{3}\right): \delta 5.92-$ $6.02(\mathrm{~m}, 1 \mathrm{H}), 5.45(\mathrm{dm}, J=17.4 \mathrm{~Hz}, 1 \mathrm{H}), 5.39$ (ddd, $J=10.8,1.3$, $1.4 \mathrm{~Hz}, 1 \mathrm{H}$ ), 4.96 (ddd, $J=47.8,6.0,1.3 \mathrm{~Hz}, 1 \mathrm{H}$ ), 3.70 (dd, $J=$ 13.6, $5.5 \mathrm{~Hz}, 1 \mathrm{H}$ ), 3.53 (d brs, $J=7.4 \mathrm{~Hz}, 1 \mathrm{H}), 2.39$ (bs, OH), 1.90$1.97(\mathrm{~m}, 1 \mathrm{H}), 1.64-1.81(\mathrm{~m}, 4 \mathrm{H}), 1.49-1.58(\mathrm{~m}, 1 \mathrm{H}), 0.99-1.30(\mathrm{~m}$, $5 \mathrm{H}) ;{ }^{13} \mathrm{C} \mathrm{NMR}\left(75 \mathrm{MHz}, \mathrm{CDCl}_{3}\right): \delta 133.4(\mathrm{~d}, J=19.6 \mathrm{~Hz}), 119.5$ (d, $J=12.5 \mathrm{~Hz}$ ), 93.9 (d, $J=171.6 \mathrm{~Hz}$ ), 73.5 (d, $J=3.1 \mathrm{~Hz}$ ), 71.3 (d, $J$ $=23.9 \mathrm{~Hz}), 40.3,29.2,28.7,26.3,26.02,25.95 ;{ }^{19} \mathrm{~F}$ NMR $(282$ $\left.\mathrm{MHz}, \mathrm{CDCl}_{3}\right) \delta-189.7(1 \mathrm{~F}, \mathrm{dt}, J=47.7,15.8 \mathrm{~Hz}, \mathrm{CH} \underline{)}),{ }^{19} \mathrm{~F}\left\{{ }^{1} \mathrm{H}\right\}$ NMR (282 $\left.\mathrm{MHz} \mathrm{CDCl}_{3}\right) \delta-189.7$ (s, 1F); HRMS (EI) calculated for $\mathrm{C}_{11} \mathrm{H}_{19} \mathrm{O}_{2} \mathrm{FNa}\left(\mathrm{M}+\mathrm{Na}^{+}\right)$225.1267; found 225.1259.

Cyclic Sulfate: (1R, 2R, 3S)-5-Cyclohexyl-4,5-dihydroxy-3fluoropent-1-ene (21);

$\mathrm{Et}_{3} \mathrm{~N}(4.3 \mathrm{~mL}, 38.6 \mathrm{mmol})$ was slowly added to a solution of fluorodiol 20 (1.35 g, $6.8 \mathrm{mmol})$ and DMAP (0.08 g, $0.64 \mathrm{mmol})$ in dry dichloromethane $(50 \mathrm{~mL})$ at $-78{ }^{\circ} \mathrm{C}$ under an argon atmosphere. After 10 min stirring, a solution of sulfuryl chloride $(0.78 \mathrm{~mL}, 9.65 \mathrm{mmol})$ in dry dichloromethane $(50 \mathrm{~mL})$ was added. The resulting mixture was stirred for an additional $4 \mathrm{~h}$ and was then quenched with $10 \%$ aq $\mathrm{NaHCO}_{3}(20 \mathrm{~mL})$. The aqueous phase was extracted into dichloromethane $(20 \mathrm{~mL} \times 3)$ and the combined organic extracts were dried over $\mathrm{MgSO}_{4}$, filtered and concentrated. The resultant orange oil was purified over silica gel (hexane/Et ${ }_{2} \mathrm{O} 9: 1$ to $8: 2$ ) to afford cyclic sulfate $21(1.52 \mathrm{~g}, 85 \%)$ as a pale yellow solid; m.p. $=74-75^{\circ} \mathrm{C} ;{ }^{1} \mathrm{H} \mathrm{NMR}$ (300 MHz, $\left.\mathrm{CDCl}_{3}\right) \delta 5.82-5.98(\mathrm{~m}, 1 \mathrm{H}), 5.59(\mathrm{dm}, J=17.2 \mathrm{~Hz}, 1 \mathrm{H})$, $5.54(\mathrm{td}, J=10.8,1.0 \mathrm{~Hz}, 1 \mathrm{H}), 5.14(\mathrm{ttd}, J=46.6,5.9,1.3 \mathrm{~Hz}, 1 \mathrm{H})$, 4.59-4.72 (m, 2H), 1.60-1.97 (m, 6H), 1.03-1.36 (m, 5H); ${ }^{13} \mathrm{C} \mathrm{NMR}$ $\left(75 \mathrm{MHz}, \mathrm{CDCl}_{3}\right) \delta 129.6(\mathrm{~d}, J=19.0 \mathrm{~Hz}), 122.1(\mathrm{~d}, J=12.0 \mathrm{~Hz}$ ), $90.4(\mathrm{~d}, J=177.1 \mathrm{~Hz}), 87.0(\mathrm{~d}, J=3.3 \mathrm{~Hz}), 81.6(\mathrm{~d}, J=29.0 \mathrm{~Hz})$, $40.2,28.4,27.2,25.7,25.4,25.1 ;{ }^{19} \mathrm{~F}$ NMR $\left(282 \mathrm{MHz}, \mathrm{CDCl}_{3}\right): \delta$ -191.7 (1F, dddd, $J=46.6,14.9,11.9,2.8 \mathrm{~Hz}, \mathrm{CHF}),{ }^{19} \mathrm{~F}\left\{{ }^{1} \mathrm{H}\right\}$ NMR $\left(282 \mathrm{MHz}, \mathrm{CDCl}_{3}\right.$ ): $\delta$-191.7 (s, 1F); HRMS (ESI, +ve) $\mathrm{m} / \mathrm{z}$ calcd for $\mathrm{C}_{11} \mathrm{H}_{17} \mathrm{O}_{4} \mathrm{FSNa}\left[\mathrm{M}+\mathrm{Na}^{+}\right]$287.0729, found 287.0736.

\section{(1R, 2R, 3S)-1-Cyclohexyl-1,3-difluoro-4-penten-2-ol (22);}

Cyclosulfate 21 (0.49 g, $1.84 \mathrm{mmol})$ was charged into a teflon flask and $\mathrm{Et}_{3} \mathrm{~N} .3 \mathrm{HF}(1.5 \mathrm{~mL}, 9.2 \mathrm{mmol})$ and $\mathrm{Et}_{3} \mathrm{~N}(2 \mathrm{~mL})$ were subsequently added under an argon atmosphere. After stirring for $16 \mathrm{~h}$ at $120{ }^{\circ} \mathrm{C}$, the reaction mixture was cooled to $0{ }^{\circ} \mathrm{C}$, quenched with ice-cold $10 \%$ aq. $\mathrm{NaHCO}_{3}(5 \mathrm{~mL})$ and then water $(10 \mathrm{~mL})$ and the product extracted into dichloromethane $(20 \mathrm{~mL}$ $x$ 3). The combined organic extracts were dried over $\mathrm{MgSO}_{4}$, 
filtered and the solvent was removed under reduced pressure. Purification over silica gel (hexane/Et $\mathrm{E}_{2} \mathrm{O}$ 10:0 to 9:1) afforded difluoride 22 as a white solid $(0.067 \mathrm{~g}, 18 \%) ; \mathrm{m} . \mathrm{p} .=74-75^{\circ} \mathrm{C},{ }^{1} \mathrm{H}$ NMR (300 MHz CDCl 3 ) : $\delta 6.02$ (ddddd, $J=25.2,17.3,10.7,6.7$, $1.1,1 \mathrm{H}), 5.43-5.52(\mathrm{~m}, 2 \mathrm{H}), 5.10(\mathrm{dm}, J=46.6 \mathrm{~Hz}, 1 \mathrm{H}), 4.07-4.23$ $(\mathrm{m}, 2 \mathrm{H}), 2.04-2.09(\mathrm{~m}, 1 \mathrm{H}), 1.62-1.1 .86(\mathrm{~m}, 5 \mathrm{H}), 1.13-1.32(\mathrm{~m}$, $5 \mathrm{H}) ;{ }^{13} \mathrm{C}$ NMR (75 MHz, $\left.\mathrm{CDCl}_{3}\right): \delta 133.0$ (dd, $\left.J=19.6 \mathrm{~Hz}\right), 119.5$ (dd, $J=12.5 \mathrm{~Hz}$ ), $90.4(\mathrm{~d}, J=177.3 \mathrm{~Hz}), 87.0(\mathrm{~d}, J=3.3 \mathrm{~Hz}$ ), 81.6 (d, $J=23.9 \mathrm{~Hz}), 40.2,28.4,27.2,25.7,25.4,25.1$; ${ }^{19} \mathrm{~F}$ NMR $(282$ $\left.\mathrm{MHz} \mathrm{CDCl}_{3}\right) \delta-189.0(1 \mathrm{~F}, \mathrm{dtd}, J=46.6,12.3,3.1 \mathrm{~Hz}, 1 \mathrm{~F}),-204.7-$ (m), ${ }^{19} \mathrm{~F}\left\{{ }^{1} \mathrm{H}\right\}$ NMR $\left(282 \mathrm{MHz}, \mathrm{CDCl}_{3}\right)-189.0(\mathrm{~s}, 1 \mathrm{~F}),-204.6(\mathrm{~s}, 1 \mathrm{~F})$; HRMS (ESI, +ve) $\mathrm{m} / \mathrm{z}$ calculated for $\mathrm{C}_{11} \mathrm{H}_{18} \mathrm{OF}_{2} \mathrm{Na}\left[\mathrm{M}+\mathrm{Na}^{+}\right]$ 227.1223, found 227.1216.

Difluoride 20 (7 mg, 1.9\%) was also recovered as white solid, m.p. $=61-62{ }^{\circ} \mathrm{C},{ }^{1} \mathrm{H} \mathrm{NMR}\left(\mathrm{CDCl}_{3}, 400 \mathrm{MHz}\right): \delta 6.04$ (dddd, $J=24.0$, $13.9,6.6,0.49 \mathrm{~Hz}, 1 \mathrm{H}), 5.47(\mathrm{dm}, J=17.3 \mathrm{~Hz}, 2 \mathrm{H}), 5.39$ (dt, $J=$ $10.8,1.2 \mathrm{~Hz}, 1 \mathrm{H}$ ), 5.24 (dddq, $J=46.3,26.7,3.2,1.4 \mathrm{~Hz}, 1 \mathrm{H}$ ), 4.37 (dddd, $J=45.5,25.8,8.8,1.9 \mathrm{~Hz}, 1 \mathrm{H}$ ), 3.89 (brs, $1 \mathrm{H}$ ), 1.60-1.90 $(\mathrm{m}, 5 \mathrm{H}), 1.11-1.34(\mathrm{~m}, 5 \mathrm{H}), 0.80-0.94(\mathrm{~m}, 1 \mathrm{H}) ;{ }^{13} \mathrm{C} \mathrm{NMR}\left(\mathrm{CDCl}_{3}\right.$, $100 \mathrm{MHz}$ ): $\delta 132.0(\mathrm{dd}, J=20.6,5.8 \mathrm{~Hz}), 119.6(\mathrm{dd}, J=11.9 \mathrm{~Hz})$, $92.3(\mathrm{dd}, J=181.8,19.9 \mathrm{~Hz}$ ), 90.5 (dd, $J=175.4,18.8 \mathrm{~Hz}$ ), 72.1 (dd, $J=26.1,4.2 \mathrm{~Hz}$ ), 39.1, 29.8, 26.43, 26.38, 26.0, 25.0; ${ }^{19} \mathbf{F}$ NMR $\left(282 \mathrm{MHz} \mathrm{CDCl}_{3}\right) \delta$-198.5-(-198.2) (m, 1ㅌ) , -207-(-207.6) $(\mathrm{m}, 1 \mathrm{~F}),{ }^{19} \mathrm{~F}\left\{{ }^{1} \mathrm{H}\right\}$ NMR $\left(282 \mathrm{MHz}, \mathrm{CDCl}_{3}\right)-198.35(\mathrm{~d}, J=10.5 \mathrm{~Hz}$, $1 F),-207.7(d, J=10.5 \mathrm{~Hz}, 1 F)$; HRMS (EI) calculated for $\mathrm{C}_{11} \mathrm{H}_{18} \mathrm{OF}_{2} \mathrm{Na} 227.1223$, found 227.1213 .

\section{1,8-Dicyclohexyl-2,7-dihydroxy-1,3,6,8-tetrafluorooct-4E-ene} (23);

A solution of difluoroalcohol $22(0.43 \mathrm{~g}, 2.11 \mathrm{mmol})$ in dichloromethane $(3 \mathrm{~mL})$ was added via syringe at room temperature and under an argon atmosphere, to a flask containing catalyst $\mathbf{M}_{\mathbf{2 3}}(0,1 \mathrm{~g}, 0.105 \mathrm{mmol})$. The reaction mixture was stirred at room temperature for $28 \mathrm{~h}$, before it was subject directly to purification by flash chromatography (petroleum ether:EtOAc 9:1 to 1:1). After solvent removal from active fractions, this gave tetrafluorodiol $\mathbf{2 3}$ as a white solid (0.235 g, 59\%); m.p. $=98-99{ }^{\circ} \mathrm{C} ;{ }^{1} \mathrm{H} \mathrm{NMR}\left(400 \mathrm{MHz}, \mathrm{CDCl}_{3}\right): \delta$ 6.02-6.13 ( $\mathrm{m}, \mathrm{AB}$ system, $2 \mathrm{H}$ ), 5.22 (d brs, $J=47.7 \mathrm{~Hz}, 2 \mathrm{H}), 4.07-$ $4.23(\mathrm{~m}, 4 \mathrm{H}), 2.17$ (brs, $2 \mathrm{H}), 1.59-1.84(\mathrm{~m}, 12 \mathrm{H}), 1.10-1.34(\mathrm{~m}$, $10 \mathrm{H}) ;{ }^{13} \mathrm{C} \mathrm{NMR}\left(\mathrm{CDCl}_{3}, 75 \mathrm{MHz}\right): \delta 128.4(\mathrm{~m}, 2 \mathrm{C}), 96.0(\mathrm{~d}, J=$ $172.3 \mathrm{~Hz}$ ), 92.3 (dd, $J=170.0,3.6 \mathrm{~Hz}), 70.7(\mathrm{t}, J=24.9 \mathrm{~Hz}), 38.3$ (d, $J=19.1 \mathrm{~Hz}), 29.2(\mathrm{~d}, J=3.7 \mathrm{~Hz}), 26.2,25.9,25.83,25.78 ;{ }^{19} \mathrm{~F}$ NMR $\left(376 \mathrm{MHz}, \mathrm{CDCl}_{3}\right) \delta$-190.3-(-190.1) (m, 2్) , -203.9-(-203.6) $(\mathrm{m}, 2 \mathrm{~F}) ;{ }^{19} \mathrm{~F}\left\{{ }^{1} \mathrm{H}\right\}$ NMR $\left(376 \mathrm{MHz}, \mathrm{CDCl}_{3}\right) \delta-190.2(\mathrm{~s}, 2 \mathrm{~F}),-203.7(\mathrm{~s}$, $2 \mathrm{~F})$; HRMS $(\mathrm{ESI},+\mathrm{ve}) \mathrm{m} / \mathrm{z}$ calculated for $\mathrm{C}_{20} \mathrm{H}_{32} \mathrm{O}_{2} \mathrm{~F}_{4} \mathrm{Na}\left[\mathrm{M}+\mathrm{Na}^{+}\right]$ 403.2236, found 403.2230.

\section{All-syn-(4E)-1,8-Dicyclohexyl-1,7-ditriflate-1,3,6,8- tetrafluorooct-4-ene (24);}

Triflic anhydride $(0.212 \mathrm{~mL}, 1.263 \mathrm{mmol})$ and pyridine $(0.097$ $\mathrm{mL}, 0.842 \mathrm{mmol}$ ) were added sequentially to a solution of tetrafluorodiol $23(0.16 \mathrm{~g}, 0.421 \mathrm{mmol})$ in dichloromethane (10 $\mathrm{mL}$ ) at $-10{ }^{\circ} \mathrm{C}$ under an argon atmosphere. After stirring for $7 \mathrm{~h}$ at room temperature, pentane $(100 \mathrm{~mL})$ was added, and the mixture was cooled to $0{ }^{\circ} \mathrm{C}$. The mixture was filtered, washed with pentane and the filtrate was concentrated under reduced pressure. The residue was triturated in ice-cold pentane (50 $\mathrm{mL}$ ), filtered, and the filtrate was concentrated in vacuo to give di-triflate $24(0.269 \mathrm{~g}, 99 \%)$ as a yellow oil which was used for the next step without further purification; ${ }^{1} \mathrm{H}$ NMR $(400 \mathrm{MHz}$, $\mathrm{CDCl}_{3}$ ): $\delta 6.00-6.16(\mathrm{~m}, 2 \mathrm{H}), 5.39$ (d brs, $\left.J=47.0 \mathrm{~Hz}, 2 \mathrm{H}\right), 5.24$ (ddt, $J=12.9,6.0,2.9 \mathrm{~Hz}, 2 \mathrm{H}$ ), $4.42(\mathrm{td}, J=47.0,5.6 \mathrm{~Hz}, 2 \mathrm{H}$ ), 1.62$1.91(\mathrm{~m}, 6 \mathrm{H}), 1.12-1.35(\mathrm{~m}, 5 \mathrm{H}) ;{ }^{19} \mathrm{~F}$ NMR $\left(376 \mathrm{MHz}, \mathrm{CDCl}_{3}\right) \delta$ $-75.0(\mathrm{~d}, J=6.3 \mathrm{~Hz}, 6 \mathrm{~F}),-188.7(\mathrm{dm}, J=47.0,2 \underline{\mathrm{F}}),-202.3$ (ddd, $J$ $=47.0,23.4,13.4 \mathrm{~Hz}, 2 \underline{\mathrm{F}}) ;{ }^{19} \mathrm{~F}\left\{{ }^{1} \mathrm{H}\right\}$ NMR $\left(376 \mathrm{MHz}, \mathrm{CDCl}_{3}\right) \delta-75.0$ $(\mathrm{d}, J=6.3 \mathrm{~Hz}, 6 \mathrm{~F}),-188.7$ (d, $J=6.3,2 \underline{\mathrm{F}}),-202.3(\mathrm{~s}, 2 \underline{\mathrm{F}})$.

\section{All-syn-(4E)-1,8-Dicyclohexyl-1,2,3,6,7,8-hexafluorooct-4-ene} 25;

The triflate 24 preparation was then dissolved in THF $(2 \mathrm{~mL})$ followed by the addition of $\mathrm{Et}_{3} \mathrm{~N} .3 \mathrm{HF}(0.617 \mathrm{~mL}, 3.79 \mathrm{mmol})$ and $\mathrm{Et}_{3} \mathrm{~N}(1.17 \mathrm{~mL}, 11.38 \mathrm{mmol})$ at room temperature under an argon atmosphere. The resulting mixture was heated to $50{ }^{\circ} \mathrm{C}$ for $8 \mathrm{~h}$, and the cooled to ambient before being diluted with dichloromethane $(20 \mathrm{~mL})$ and water $(10 \mathrm{~mL})$. The equeous layer was extracted into dichloromethane $(10 \times 2 \mathrm{~mL})$ at the combined organic extracts was dried over $\mathrm{MgSO}_{4}$, filtered and concentrated. The residue was purified over silica gel (pentane: ether 1:0 to 8:2) to furnish olefin $\mathbf{2 5}(13 \mathrm{mg}, 8 \%)$ as a white solid; m.p. $=107-108{ }^{\circ} \mathrm{C},{ }^{1} \mathrm{H} \mathrm{NMR}\left(300 \mathrm{MHz}, \mathrm{CDCl}_{3}\right): \delta 5.94-6.13(\mathrm{~m}$, $2 \mathrm{H}$ ), $5.27(\mathrm{dm}, J=47.2 \mathrm{~Hz}, 2 \mathrm{H}$ ), 4.59 (ddddd, $J=47.5,29.3,15.5$, $7.1,1.9 \mathrm{~Hz}, 2 \mathrm{H}$ ), 4.14 (tddd, $J=47.0,27.5,8.7,1.4 \mathrm{~Hz}, 2 \mathrm{H}), 1.65-$ $2.04(\mathrm{~m}, 12 \mathrm{H}), 0.80-1.39(\mathrm{~m}, 1 \mathrm{OH}) ;{ }^{13} \mathrm{C} \mathrm{NMR}\left(\mathrm{CDCl}_{3}, 75 \mathrm{MHz}\right): \delta$ $128.4(\mathrm{~m}, 2 \mathrm{C}), 94.7$ (ddd, $J=178.2,19.3,7.1 \mathrm{~Hz}), 91.5$ (ddd, $J=$ 188.6, 23.3, $19.6 \mathrm{~Hz}$ ), 90.8 (ddd, $J=176.6,23.3,7.1 \mathrm{~Hz}$ ), 37.6 (dd, $J=19.4,4.3 \mathrm{~Hz}$ ), 28.5 (d, $J=4.5 \mathrm{~Hz}), 27.9$ (d, $J=7.6 \mathrm{~Hz}), 26.0$, 25.5, 25.3; ${ }^{19} \mathrm{~F}$ NMR $\left(282 \mathrm{MHz}, \mathrm{CDCl}_{3}\right) \delta-191.6-(-191.3)(\mathrm{m}, 2 \underline{\mathrm{F}})$, -204.0-(-203.7) (m, 2F); -207.6-(-207.1) (m, 2F); ${ }^{19} \mathrm{~F}\left\{{ }^{1} \mathrm{H}\right\}$ NMR $\left(282 \mathrm{MHz}, \mathrm{CDCl}_{3}\right)-191.5(\mathrm{~d}, J=14.8 \mathrm{~Hz}, 2 \mathrm{~F}),-203.8(\mathrm{~d}, J=10.1$ $\mathrm{Hz}, 2 \mathrm{~F}),-207.4$ (dd, $J=14.8,10.1 \mathrm{~Hz}, 2 \mathrm{~F})$; MS (ESI, +ev) $\mathrm{m} / \mathrm{z} 407$ $\left(\mathrm{M}+\mathrm{Na}^{+}\right)$, HRMS (ESI, +ve) calcd for $\mathrm{C}_{20} \mathrm{H}_{30} \mathrm{~F}_{4} \mathrm{Na}$ calculated 407.2149, found 407.2136.

\section{All-syn-1,8-Dicyclohexyl-1,2,3,6,7,8-hexafluorooctane 9;}

Palladium-on-charcoal $(10 \%, 10 \mathrm{mg}, 0.038 \mathrm{mmol})$ was added to a solution of olefin 25 (13 mg, $0.034 \mathrm{mmol}$ ) in ethyl acetate (10 $\mathrm{mL}$ ) and the mixture was deoxygenated by evacuation and flushed three times with hydrogen. After stirring under hydrogen for $2 \mathrm{~h}$, the mixture was filtered through celite, washed with ethyl acetate and the solution was concentrated at reduced pressure to give hexafluoroalkane 9 as a white crystalline solid (11 mg, 98\%); m.p. $=119-120{ }^{\circ} \mathrm{C},[\alpha]_{\mathrm{D}}+12.3(\mathrm{c}$ $\left.0.52, \mathrm{CHCl}_{3}\right) ;{ }^{1} \mathrm{H}$ NMR $\left(\mathrm{CDCl}_{3}, 300 \mathrm{MHz}\right): \delta$ 4.41-4.93 (m, 4H), 4.29 (dddd, $J=47.1,25.1,7.1,3.1 \mathrm{~Hz}, 2 \mathrm{H}), 1.65-2.04(\mathrm{~m}, 16 \mathrm{H})$,

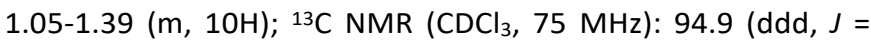
172.2, 19.3, 7.1 Hz), 91.6 (ddd, $J=188.6,23.3,19.6 \mathrm{~Hz}$ ), 90.8 (ddd, $J=176.6,23.3,7.1 \mathrm{~Hz}$ ), 37.8 (dd, $J=19.4,4.3 \mathrm{~Hz}$ ), 28.2 (d, $J=4.5 \mathrm{~Hz}), 27.8(\mathrm{~d}, J=7.6 \mathrm{~Hz}), 26.0,25.7,25.6(\mathrm{dt}, J=7.7,3.8$ $\mathrm{Hz}), 25.3 ;{ }^{19} \mathrm{~F}$ NMR $\left(282 \mathrm{MHz}, \mathrm{CDCl}_{3}\right) \delta-197.6-(-197.2)(\mathrm{m}, 2 \underline{\mathrm{F}})$, -204.9 (dddd, $J=47.4,26.4,15.7,11.5 \mathrm{~Hz}, 2 \underline{\mathrm{F}}$ ); -209.1-(-208.7) $(\mathrm{m}, 2 \mathrm{~F}) ;{ }^{19} \mathrm{~F}\left\{{ }^{1} \mathrm{H}\right\}$ NMR $\left(282 \mathrm{MHz}, \mathrm{CDCl}_{3}\right)-197.5(\mathrm{~d}, J=13.1 \mathrm{~Hz}, 2 \mathrm{~F})$, -204.9 (d, $J=11.1 \mathrm{~Hz}, 2 \mathrm{~F}),-208.9(\mathrm{dd}, J=13.1,11.1 \mathrm{~Hz}, 2 \mathrm{~F})$; MS 
(ESI, +ev) $m / z 409\left(\mathrm{M}+\mathrm{Na}^{+}, 100 \%\right)$, HRMS (ESI, +ve) calculated for $\mathrm{C}_{20} \mathrm{H}_{32} \mathrm{~F}_{6} \mathrm{Na}$ 409.2306, found 409.2311.

\section{DFT Computations}

A partial conformational analysis was performed for $\mathrm{C}_{8} \mathrm{~F}_{6} \mathrm{H}_{10} \mathrm{Cy}_{2}$ $\left(9, \mathrm{Cy}=\right.$ cyclohexyl) and $\mathrm{a}_{8} \mathrm{~F}_{8} \mathrm{H}_{8} \mathrm{Cy}_{2}$ model (26). Structures were fully optimised in the gas phase at the B3LYP24/6-31G* level of density functional theory. The minimum character of the stationary points were verified through calculation of the harmonic vibrational frequencies at that level, which were all real, and which were used to evaluate standard thermodynamic corrections to enthalpies and free energies (at standard pressure and temperature). Energies were refined through full optimisation at the B3LYP-D3/6-311+G** level (including Grimme's three-body dispersion correction ${ }^{25}$ with BeckeJohnson damping ${ }^{26}$ ) in a solvent model, the latter employing the polarizable conductor variant of the polarizable continuum model (CPCM), ${ }^{27}$ using the parameters of dichloromethane and the default options in Gaussian 09,28 which was used for all calculations.

\section{Conflicts of interest}

There are no conflicts to declare.

\section{Acknowledgements}

We thank the EPSRC for financial support. M.B. thanks the School of Chemistry and EaStCHEM for support. Computations were performed on a local Xeon cluster maintained by $\mathrm{Dr}$. $\mathrm{H}$. Fruchtl.

\section{Notes and references}

1 (a) Y. Zafrani, D. Yeffet, G. Sod-Moriah, A. Berliner, D. Amir, D. Marciano, E. Gershonov, S. Saphier, J. Med. Chem., 2017, 60, 797-804; (b) Q. A. Huchet, N. Trapp, B. Wagner, H. Fischer, N. A. Kratochwil, E. M. Carreira, K. Müller, J. Fluorine Chem., 2017, 198, 34-46; (c) Q. A. Huchet, B. Kuhn, B. M. Wagner, N. A. Kratochwil, H. Fischer, M. Kansey, D. Zimmerli, E. M. Carreira, K. Müller, J. Med. Chem., 2015, 58, 9041 - 9060; (d) D. O'Hagan, Chem. Soc. Rev., 2008, 37, 308 - 319.

2 (a) K. Yamamoto, J. Li, J. A. O. Garber, J. D. Rolfes, G. B. Boursalian, J. C. Borghs, C. Genicot, J. Jacq, M. van Gastel, F. Neese, T. Ritter, Nature, 2018, 554, 511-514; (b) K. Müller, C. Faeh, F. Diederich, F; Science, 2007, 317, 1881-1886; (c) E. P. Gillis, J. K. Eastman, M. D. Hill, D. J. Donnelly, N. A. Meanwell, J. Med. Chem., 2015, 58, 8315-8359; M. G. Campbell, T. Ritter, Chem. Rev., 2015, 115, 612-633.

3 (a) N. Al-Maharik, P. Kirsch, A. M. Z. Slawin, D. B. Cordes and David O'Hagan, Org. Biomol. Chem., 2016, 14, 9974-9980; (b) L. Hunter, P. Kirsch, A. M. Z. Slawin, and D. O'Hagan, Angew. Chem. Int. Ed., 2009, 48, 5457-5460; (c) D. Farran, A. M. Z. Slawin, P. Kirsch, D. O'Hagan, J. Org. Chem., 2009, 74, 71687171; (d) L. Hunter, P. Kirsch, J. T. G. Hamilton, D.O'Hagan,
Org. Biomol. Chem., 2008, 6, 3105-3108; (e) L. Hunter, A. M. Z. Slawin, P. Kirsch, D. O'Hagan, Angew. Chem. Int. Ed., 2007, 46, 7887-7890; (f) M. Nicoletti, M. Bremer, P. Kirsch, D. O'Hagan, Chem. Commun., 2007, 5075-5077; (g) L. Hunter, D. O'Hagan, A. M. Z. Slawin, J. Am. Chem. Soc., 2006, 128, 1642216423; (h) M. Nicoletti, D. O'Hagan, A. M. Z. Slawin, J. Am. Chem. Soc., 2005, 127, 482-483.

4 (a) Z. Fang, D. B. Cordes, A. M. Z. Slawin, D. O'Hagan; Chem Commun., 2019, 55, 10539 - 10542; (b) Z. Fang, N. AlMuharik, A. M. Z. Slawin, M. Bühl, D. O'Hagan, Chem Commun., 2016, 52, 5116 - 5119; (c) N. S. Keddie, A. M. Z. Slawin, T. Lebl, D.Philp, D. O'Hagan; Nature Chem., 2015, 7, 483-488; (d) A. J. Durie, A. M. Z. Slawin, T. Lebl, P. Kirsch, D. O'Hagan; Chem Commun., 2012, 48, 9643-9645; A. J. Durie, A. M. Z. Slawin, T. Lebl, D. O'Hagan; Angew. Chemie Int. Ed., 2012, 51, 10086 - 10088.

5 (a) R. Cheerlavancha, A. Ahmed, Y. C. Leung, A. Lawer, Q. Q. Liu, M. Cagnes, H. C. Jang, X. G. Hu, L. Hunter, Beilstein. J. Org. Chem., 2017, 13, 2316-2325; (b) A. R. Patel, L. Hunter, M. M. Bhadbhade, F. Liu; Eur. J. Org. Chem., 2014, 2584-2593; (c) R. Cheerlavancha, A. Lawer, M. Cagnes, M. Bhadbhade, L. Hunter, Org. Lett., 2013, 15, 5562-5565.

6 (a) P. Bentler, N. Erdeljac, K. Bussmann, M. Ahlqvist, L. Knerr, K. Bergander, C. G. Daniliuc, R. Gilmour, Org. Lett., 2019, 21, 7741-7745; (b) N. Erdeljac, K. Bussmann, A. Schöler, F. K. Hansen, R. Gilmour, ACS Med. Chem. Lett. 2019, 10,13361340, (c) I. G. Molnar, R. Gilmour, J. Am. Chem. Soc., 2016, 138, 5004-5007; (d) S. M. Banik, J. W. Medley, E. N. Jacobsen, J. Am. Chem. Soc., 2016, 138, 15, 5000-5003.

7 (b) Z. Nairoukh, M. Wollenburg, C. Schlepphorst, K. Bergander, F. Glorius, Nature Chem. 2019, 11, 264-270 (c) M. P. Wiesenfeldt, Z. Nairoukh, W. Li, F. Glorius, Science, 2017, 357, 908-912.

8 S. Fischer, N. Huwyler, S. Wolfrum, E.M. Carreira, Angew. Chem. Int. Ed., 2016, 55, 2555-2558.

9 A. Rodil, S. Bosisio, M. S. Ayoup, L. Quinn, D. B. Cordes, A. M. Z. Slawin, C. D. Murphy, J. Michel, D. O'Hagan; Chem. Sci., 2018, 9, $3023-3028$.

10 N. Santschi, R. Gilmour, Nature Chem., 2015, 7, 467 - 468.

11 (a) N. Diaz, F. Jimenez-Gravalos, D. Suarez, E. Francisco, angel Martın-Penda, Phys. Chem. Chem. Phys., 2019, 21, $25258-$ 25275; (b) D. Wu, A. Tian and H. Sun, J. Phys. Chem. A., 1998, 102, 9901-9905.

12 (a) E. El-Sayed, N. K. Anand, E. M. Carreira, Org. Lett., 2001, 3, 3017-3020; (b) H. Sasaki, D. Boyall, and E. M. Carreira, Helv. Chim. Acta., 2001, 84, 964-971; (c) Frantz, D. E.; Fassler, R.; Tomooka, C. S.; Carreira, E. M. Acc. Chem. Res., 2000, 33, 373338.

13 C. T. Meta, K. Koide, Org. Lett., 2004, 6, 1785-1787.

14 (a) S. L. Schreiber, T. S. Schreiber, and D. B. Smith, J. Am. Chem. Soc., 1987, 109, 1525-1529; (b) T. Katsuki, and K. B. Sharpless, J. Am. Chem. Soc., 1980, 102, 5974-5976.

15 S. Dandapani, D. P. Curran, Tetrahedron, 2002, 58, 3855-3864.

16 (a) S. F. Martin and J. A. Dodge, Tetrahedron Lett., 1991, 32, 3017-3020; (b) E. J. Corey, H. Cho, C. Rücker, D. H. Hua, Tetrahedron Lett., 1981, 22, 3455.

17 T. W. Greene, P. G. W. Wuts, Protective Groups in Organic Synthesis, 3rd Ed.; Wiley-Interscience: New York, 1999.

18 D. B. Dess, J. C. Martin, J. Org. Chem., 1983, 48, 22, 4155-4156.

19 D. O'Hagan, N. Al-Maharik, Aldrich Chemica Acta, 2011, 44, 65-75.

20 A. J. Durie T. Fujiwara, N. Al-Maharik, A. M. Z. Slawin, D. O'Hagan, J. Org Chem., 2014, 79, 8228-8233.

21 (a) D. R. Boyd, N. D. Sharma, M. Kaik, P. B. A. Mclntyre, J. F. Malone and P. J. Stevenson, Org Biomol Chem., 2014,12, 2128-2136; (b) Y. Gao, K. B. Sharpless, J. Am. Chem. Soc., 1988, 110, 7538 - 7539. 
22 S. Manzini, C. A. Urbina Blanco, D. J. Nelson, A. Poater, T. Lebl, S. Meiries, A. M. Z. Slawin, L. Falivene, L. Cavallo, S. P. Nolan, J. Organometallic Chem., 2015, 780, 43-48.

23 R. J. Abrahams, L. Cavalli. Mol. Phys., 1965, 9, 67-75.

24 (a) A. D. J. Becke; Chem. Phys., 1993, 98, 5648-5642; (b) C. Lee, W. Yang, R. G. Parr; Phys. Rev. B., 1988, 37, 785-789.

25 (a) S. Grimme, J. Antony, S. Ehrlich, H. Krieg, J. Chem. Phys., 2010, 132, 154104; (b) S. Grimme, S. Ehrlich, L. Goerigk, J. Comput. Chem., 2011, 32, 1456-1465.; (c) T. Risthaus, S. Grimme, J. Chem. Theory Comput., 2013, 9, 1580-1591.

26 (a) A. D. Becke, E. R. Johnson, J. Chem. Phys., 2005, 122, 154104; (b) E. R. Johnson, A. D. Becke, J. Chem. Phys., 2006, 124, 174104.

27 (a) M. Cossi, N. Rega, G. Scalmani, V. Barone, J. Comp. Chem. 2003, 24, 669-681; (b) J. Tomasi, B. Mennucci, R. Cammi, Chem. Rev. 2005, 105, 2999-3093.

28 M. J. Frisch et al, Gaussian 09, Rev. A.02, Wallingford CT, 2009 (see Supporting Information for full citation). 